\title{
Antibiotics for Leptospirosis
}

David Brett-Major

University of Nebraska Medical Center, david.brettmajor@unmc.edu

Rodney Coldren

Uniformed Services University

Tell us how you used this information in this short survey.

Follow this and additional works at: https://digitalcommons.unmc.edu/coph_epidem_articles

Part of the Epidemiology Commons

\section{Recommended Citation}

Brett-Major, David and Coldren, Rodney, "Antibiotics for Leptospirosis" (2012). Journal Articles:

Epidemiology. 26.

https://digitalcommons.unmc.edu/coph_epidem_articles/26

This Article is brought to you for free and open access by the Epidemiology at DigitalCommons@UNMC. It has been accepted for inclusion in Journal Articles: Epidemiology by an authorized administrator of DigitalCommons@UNMC.For more information, please contact digitalcommons@unmc.edu. 


\section{(E) Cochrane Library}

Cochrane Database of Systematic Reviews

\section{Antibiotics for leptospirosis (Review)}

Brett-Major DM, Coldren R

Brett-Major DM, Coldren R.

Antibiotics for leptospirosis.

Cochrane Database of Systematic Reviews 2012, Issue 2. Art. No.: CD008264.

DOI: 10.1002/14651858.CD008264.pub2.

www.cochranelibrary.com 
TABLE OF CONTENTS

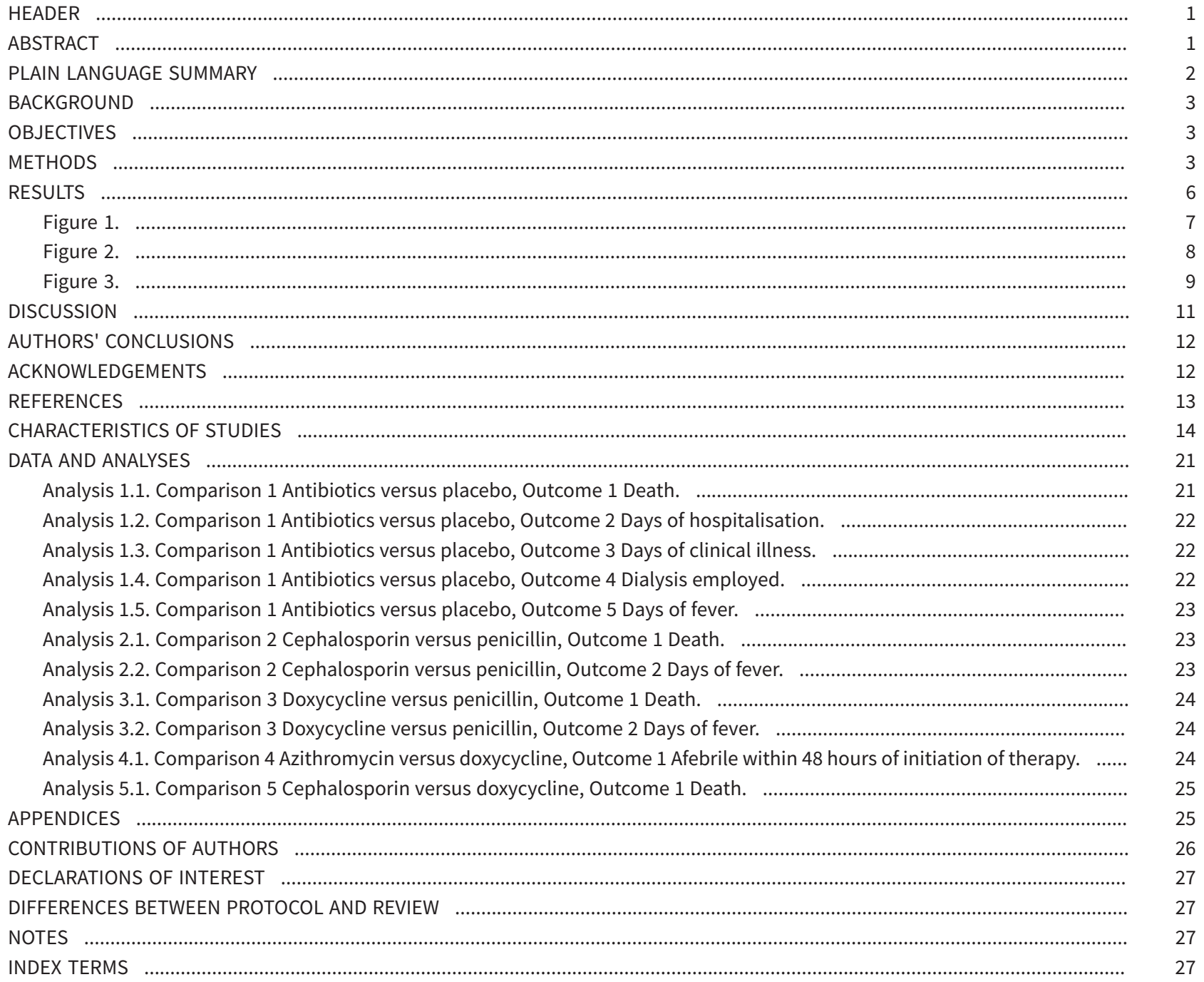


[Intervention Review]

\section{Antibiotics for leptospirosis}

David M Brett-Major ${ }^{1}$, Rodney Coldren²

1U.S. Military Tropical Medicine, Navy Medicine Manpower, Personnel, Training and Education Command (NAVMED MPT\&E), Bethesda, MD, USA. ${ }^{2}$ Department of Preventive Medicine and Biometrics, Uniformed Services University, Bethesda, USA

Contact address: David M Brett-Major, U.S. Military Tropical Medicine, Navy Medicine Manpower, Personnel, Training and Education Command (NAVMED MPT\&E), 8901 Wisconsin Avenue, Bethesda, MD, 20889-5611, USA. dmbrettmajor@gmail.com, David.Brett-

Major@med.navy.mil.

Editorial group: Cochrane Hepato-Biliary Group.

Publication status and date: New, published in Issue 2, 2012.

Citation: Brett-Major DM, Coldren R. Antibiotics for leptospirosis. Cochrane Database of Systematic Reviews 2012, Issue 2. Art. No.: CD008264. DOI: 10.1002/14651858.CD008264.pub2.

Copyright (c) 2012 The Cochrane Collaboration. Published by John Wiley \& Sons, Ltd.

\section{A B S T R A C T}

\section{Background}

Leptospirosis has a wide-ranging clinical and public health impact. Leptospira are globally distributed. Case attack rates are as high as 1:4 to 2:5 persons in exposed populations. In some settings mortality has exceeded $10 \%$ of infected people. The benefit of antibiotic therapy in the disease has been unclear.

\section{Objectives}

We sought to characterise the risks and benefits associated with use of antibiotic therapy in the management of leptospirosis.

\section{Search methods}

We searched the The Cochrane Hepato-Biliary Group Controlled Trials Register, the Cochrane Central Register of Controlled Trials (CENTRAL) in The Cochrane Library, MEDLINE, EMBASE, and Science Citation Index Expanded regardless of study language. This was augmented by a manual search. The last date of search was November, 2011.

\section{Selection criteria}

To be included in assessment of benefits, trials had to specifically assess the use of antibiotics in a randomised clinical trial. A broad range of study types were incorporated to seek potential harms.

\section{Data collection and analysis}

Included trials were systematically abstracted, as were excluded studies for the purposes of assessing harms. Analyses were conducted in accordance with The Cochrane Handbook and practices of The Cochrane Hepato-Biliary Group.

\section{Main results}

Seven randomised trials were included. Four trials with 403 patients compared an antibiotic with placebo or no intervention. Three trials compared at least one antibiotic regimen with another antibiotic regimen. The trials all had high risk of bias. The trials varied in the severity of leptospirosis among trial patients. The ability to group data for meta-analysis was limited. While all four trials that compared antibiotics with placebo reported mortality and used parenteral penicillin, there were no deaths in two of them. Since odds ratio calculations cannot employ zero-event trials, only two trials contributed to this estimate. The number of deaths were $16 / 200(8.0 \%)$ in the antibiotic arm versus $11 / 203(5.4 \%)$ in the placebo arm giving a fixed-effect OR 1.56 (95\% Cl 0.70 to 3.46). The random-effects OR is 1.16 (95\% Cl 0.23 to 5.95). The heterogeneity among these four trials for the mortality outcome was moderate ( $12=50 \%)$. Only one trial ( 253 patients) reported days of hospitalisation. It compared parenteral penicillin to placebo without significant effect of therapy (8.9 versus 8.8 days; mean difference (MD) 0.10 days, $95 \% \mathrm{Cl}-0.83$ to 1.03 ). The difference in days of clinical illness was reported in two of these trials ( 71 patients). While parenteral 
penicillin therapy conferred 4.7 to 5.6 days of clinical illness in contrast to 7.7 to 11.6 days in the placebo arm, the size of the estimate of effect increased but statistical significance was lost under the random-effect model (fixed-effect: MD -2.13 days, $95 \% \mathrm{Cl}-2.46$ to -1.80 ; random-effects: $\mathrm{MD}-4.04,95 \% \mathrm{Cl}-8.66$ to 0.58$). \mathrm{I}^{2}$ for this outcome was high (81\%). When duration of fever alone was assessed between antibiotics and placebo in a single trial (79 patients), no significant difference existed (6.9 versus 6.6 days; $\mathrm{MD} 0.30,95 \% \mathrm{Cl}-1.26$ to 1.86 ). Two trials with 332 patients in relatively severe and possibly late leptospirosis, resulted in trends towards increased dialysis when penicillin was used rather than placebo, but the estimate of effect was small and did not reach statistical significance (42/163 (25.8\%) versus 31/169 (18.4\%); OR 1.54, 95\% Cl 0.91 to 2.60). When one antibiotic was assessed against another antibiotic, there were no statistically significant results. For mortality in particular, these comparisons included cephalosporin versus penicillin ( 2 trials, $6 / 176$ (3.4\%) versus $9 / 175$ (5.2\%); fixed-effect: OR $0.65,95 \% \mathrm{Cl} 0.23$ to 1.87 , I2= 16\%), doxycycline versus penicillin (1 trial, $2 / 81$ (2.5\%) versus $4 / 89(4.5)$; OR $0.54,95 \% \mathrm{Cl} 0.10$ to 3.02 ), cephalosporin versus doxycycline ( 1 trial, $1 / 88$ (1.1\%) versus $2 / 81(2.5 \%)$; OR $0.45,95 \% \mathrm{Cl} 0.04$ to 5.10$)$. There were no adverse events of therapy which reached statistical significance.

\section{Authors' conclusions}

Insufficient evidence is available to advocate for or against the use of antibiotics in the therapy for leptospirosis. Among survivors who were hospitalised for leptospirosis, use of antibiotics for leptospirosis may have decreased the duration of clinical illness by two to four days, though this result was not statistically significant. When electing to treat with an antibiotic, selection of penicillin, doxycycline, or cephalosporin does not seem to impact mortality nor duration of fever. The benefit of antibiotic therapy in the treatment of leptospirosis remains unclear, particularly for severe disease. Further clinical research is needed to include broader panels of therapy tested against placebo.

\section{PLAIN LANGUAGE SUMMARY}

\section{Antibiotics for the treatment of leptospirosis}

Leptospirosis is a common disease both in the developed and developing world. It is caused by a bacteria spread by the urine of animals. People travelling, agricultural field workers, hunters, homeless, and others with close animal contact are groups that, in particular, can get leptospirosis. Like many common infections, most people infected with this disease do not feel sick. When people do feel sick, in some instances up to 1 out of every 10 people have died. Whether or not antibiotics should be used, and if used which antibiotic should be used have been matters for debate for many years. This review identified and assessed seven clinical trials that tested antibiotics in patients sick with leptospirosis. Four of these trials compared intravenous penicillin to a placebo. Three of the trials looked at differences between different antibiotics. All trials had high risk of systematic errors (bias) and of random errors (play of chance). When looked at together, these trials do not answer the basic questions about whether or not antibiotics should be used. Part of the reason for this is that there is a wide range of severity among people ill with the disease. Additional randomised clinical trials are needed. Nonetheless, these trials suggest that antibiotics administered to patients who are sick with leptospirosis may make patients feel better two days earlier than they otherwise would have improved. However, it is also possible that when patients are severely ill, penicillin therapy might increase the risk of death or dialysis in comparison to those who receive no antibiotics. Other antibiotics have not been tested in this way. Despite the lack of evidence, if a clinician chooses to treat leptospirosis with an antibiotic, there does not seem to be any difference between the appropriate use of intravenous penicillin, intravenous cephalosporin, doxycyline, or azithromycin. But, for this they have not been tested to the same extent as intravenous penicillin. 


\section{B A C K G R O U N D}

Leptospira species have a wide geographic distribution in nature and are recognised as causing zoonotic clinical disease (leptospirosis) predominantly in the Americas, Carribean, and Asia (Pappas 2008). While World Health Organization (WHO) guidelines admit that both morbidity and mortality in leptospirosis are variably determined, the guidelines strongly promote the use of targeted antibiotic therapy as soon as leptospirosis is considered a leading element of the differential diagnosis in an ill patient (WHO 2003). This is despite recognition that benefits of therapy historically have been unclear (Bharti 2003). Point of care diagnosis for leptospirosis is not in use. While clinical scoring exists, serologic assays, ideally with acute and convalescent sera and culture employing specialised media, are required.

Deaths occur in outbreaks most commonly from renal failure and pulmonary haemorrhage. Proportions of symptomatic disease among exposed persons have ranged from $26 \%$ to $40 \%$ in small studies among immune naive populations (Russell 2003; Sejvar 2003; Hadad 2006). Mortality among symptomatic patients also may be high. After the 2005 flooding in Guyana, one group reported six deaths among 40 clinical presentations to a referral centre (Liverpool 2008).

We sought to better define the role of antibiotic therapy in patients with leptospirosis and update a previously published Cochrane systematic review (Guidugli 2000). That review pooled three trials and demonstrated no statistically significant benefit for either mortality or number of days hospitalised when doxycycline and penicillin were compared with placebo.

\section{O B JECT I VES}

To assess the beneficial and harmful effects of antibiotics for the treatment of leptospirosis.

\section{METHODS}

\section{Criteria for considering studies for this review}

\section{Types of studies}

We considered for inclusion all randomised clinical trials studying antibiotics for the treatment of leptospirosis regardless of year, language, form of publication, blinding, or comparator (Higgins 2011). In order to assess potential harm, we searched for contributory cohort studies, case-control studies, and quasirandomised studies.

\section{Types of participants}

All infected patients were included, though we anticipated that most participants would be victims of seasonal flooding, agricultural workers in endemic regions, veterinarians, and other high-risk occupations as well as high-risk activity travellers, such as troops and eco-tourists, potentially exposed to Leptospira infection.

\section{Types of interventions}

Administration of antibiotic expressly given for the treatment of leptospirosis versus placebo, no intervention, or another antibiotic.
We did not exclude studies based upon type of antibiotic, dose, dose interval, route of administration, or timing of dose, though these factors were relevant for pooling. We allowed cointerventions when equally administered to all trial groups.

\section{Types of outcome measures}

We evaluated selected trials for the following outcome measures:

\section{Primary outcomes}

- Overall mortality.

- Leptospirosis mortality (confirmed by laboratory diagnosis).

- Hospitalisation (regardless of cause).

- Leptospirosis hospitalisation (confirmed by laboratory diagnosis).

- Among those with hospitalisation for leptospirosis confirmed by laboratory diagnosis, ventilator requirement.

- Among those with hospitalisation for leptospirosis confirmed by laboratory diagnosis, dialysis requirement.

\section{Secondary outcomes}

- Days lost from work or travel.

- Among those with hospitalisation for leptospirosis confirmed by laboratory diagnosis and ventilated, number of days on mechanical ventilation.

- Among those with hospitalisation for leptospirosis confirmed by laboratory diagnosis and dialyzed, number of days on dialysis.

- Adherence to assigned intervention.

- All adverse events. An adverse event defined as any untoward medical occurrence in a patient in any trial group, regardless of association with the intervention, but that results in a dose reduction, discontinuation of treatment, or registration as an adverse event (ICH-GCP 1996). We characterised events into the following strata:

* Minor not requiring intervention.

* Minor requiring intervention.

* Requiring hospitalisation or resulting in long-term disability.

* Death (ICH-E3 1995).

\section{Search methods for identification of studies}

We performed electronic and manual searches.

\section{Electronic searches}

We searched The Cochrane Hepato-Biliary Group Controlled Trials Register (Gluud 2011), the Cochrane Central Register of Controlled Trials (CENTRAL) in The Cochrane Library, MEDLINE, EMBASE, and Science Citation Index Expanded (Royle 2003). Search strategies with the time span of the searches are given in Appendix 1. Once we selected a trial for inclusion, we used its bibliography to search for candidate trials. In MEDLINE, we used the 'Related links' feature to search the 25 most related publications to each selected study.

\section{Searching other resources}

We attempted contact with the authors of included trials in press within the previous 20 years. We provided a draft of this review in order to afford them an opportunity to supplement study information to better inform study description or incorporated data. Such correspondences were sent on 15 May 2011. 


\section{Data collection and analysis}

We followed the instructions in The Cochrane Handbook for Systematic Reviews of Interventions (Higgins 2011) and the Cochrane Hepato-Biliary Group Module (Gluud 2011) for data collection and analysis.

\section{Selection of studies}

Both authors independently reviewed the entire list of candidate studies obtained by databases search for compliance with the selection requirements. The authors did not have disagreement on inclusion of individual trials; however, they, if necessary, had available arbitration through The Cochrane Hepato-Biliary Group Editorial Team Office.

\section{Data extraction and management}

We abstracted each selected study with two independent abstractions.

As available, we extracted the following information from each selected study:

- Study and publication identifiers

- Database index number, first author, journal, year of publication, and language.

- Location, period of intervention, duration participants were followed.

- Funding source.

- Study design

- Inclusion and exclusion criteria.

- Sample size (premise, calculation).

- Outcome measures.

- Randomisation and how randomised participants were allocated across groups.

- Definitions of outcomes, in particular clinical and laboratory diagnosis.

- Assigned interventions and control.

- Who was blinded and how concealment was accomplished.

- Dichotomous: If not selected for inclusion for analysis of benefit, should it be abstracted to inform analysis of harms? (if yes, abstract).

- Dichotomous: If not selected for inclusion for analysis of benefit, should it be abstracted to inform the discussion? (if yes, abstract).

- Participant demographics

- Age.

- Sex.

- Nature of exposure (agricultural worker, eco-tourist, etc).

- Results

- Observed outcomes as published and augmented by author query.

- Follow-up.

- Completion rates by trial arms.

- Type of analysis (intention-to-treat sought).

\section{Assessment of risk of bias in included studies}

We followed the instructions given in the Cochrane Handbook for Systematic Reviews of Interventions (Higgins 2011) and the Cochrane Hepato-Biliary Group Module (Gluud 2011). Due to the risk of biased overestimation of intervention effects in randomised trials with inadequate methodological quality (Schulz 1995; Moher 1998; Kjaergard 2001; Wood 2008), we looked at the influence of methodological quality of the trials on the results by evaluating the risk of bias domains described below. When information was not available in the published trial, we contacted the authors in an attempt to assess each trial fully. Explicit methodologic grading criteria are recommended standard in the Cochrane Hepato-Biliary Group Module (Gluud 2011).

\section{Allocation sequence generation}

- Low risk of bias: sequence generation was achieved using computer random number generation or a random number table. Drawing lots, tossing a coin, shuffling cards, and throwing dice are adequate if performed by an independent adjudicator.

- Uncertain risk of bias: the trial is described as randomised, but the method of sequence generation was not specified.

- High risk of bias: the sequence generation method is not, or may not be, random. Quasi-randomised studies, those using dates, names, or admittance numbers in order to allocate patients are inadequate and will be excluded for the assessment of benefits but not for harms.

\section{Allocation concealment}

- Low risk of bias: allocation was controlled by a central and independent randomisation unit, sequentially numbered, opaque and sealed envelopes or similar, so that intervention allocations could not have been foreseen in advance of, or during, enrolment. - Uncertain risk of bias: the trial was described as randomised, but the method used to conceal the allocation was not described so that intervention allocations may have been foreseen in advance of, or during, enrolment.

- High risk of bias: if the allocation sequence was known to the investigators who assigned participants, or if the study was quasirandomised. Quasi-randomised studies will be excluded for the assessment of benefits but not for harms.

\section{Blinding}

- Low risk of bias: the trial was described as blinded, the parties that were blinded, and the method of blinding was described so that knowledge of allocation was adequately prevented during the trial. - Uncertain risk of bias: the trial was described as blinded, but the method of blinding was not described so that knowledge of allocation was possible during the trial.

- High risk of bias, the trial was not blinded so that the allocation was known during the trial.

\section{Incomplete outcome data}

- Low risk of bias: the numbers and reasons for dropouts and withdrawals in all intervention groups were described, or if it was specified that there were no dropouts or withdrawals.

- Uncertain risk of bias: the report gave the impression that there had been no dropouts or withdrawals, but this was not specifically stated.

- High risk of bias: the number or reasons for dropouts and withdrawals were not described.

Selective outcome reporting 
- Low risk of bias: death and dialysis are reported on.

- Uncertain risk of bias: either death or dialysis is not reported on, or are not reported fully, or it is unclear whether data on these outcomes were recorded or not.

- High risk of bias: either death or dialysis is not reported on; data on these outcomes were likely to have been recorded.

\section{Other bias}

While each study was assessed qualitatively for unexpected sources of bias, each trial was assessed in particular for funding and academic biases.

- Low risk of bias: the trial appears to be free of other components that could put it at risk of bias. Funding - sources clearly delineated and non-commercial; Academic - searchable literature from the study group which demonstrated balanced conclusions on the topic of publication.

- Uncertain risk of bias: the trial may or may not be free of other components that could put it at risk of bias. Funding - not disclosed or incomplete; Academic - not discernible due to lack of searchable literature.

- High risk of bias: there are other factors in the trial that could put it at risk of bias, eg, for-profit involvement, authors have conducted trials on the same topic etc. Funding - commercial sponsors particularly if lacking statement on level of participation in study execution by sponsors; Academic - searchable literature from the study group which demonstrated persistently themed conclusions on the topic of publication.

We abstracted selected studies independently of each other and without masking of the trial names. Mediation was not necessary. We used an abstraction form detailing information for global bias risk assessment and potential subgroup analyses.

We assessed selection and observation biases by abstracting core trial methodologies to include inclusion and exclusion criteria, randomisation, blinding, outcome definitions, and follow-up. We used each trial's enrolling definitions, duration of participant following, and surveillance methods in order to assess lead and lagtime biases.

Trials assessed as having 'low risk of bias' in all individual domains were considered 'trials with low risk of bias'. Trials assessed as having 'uncertain risk of bias' or 'high risk of bias' in one or more of the specified individual domains were considered trials with 'high risk of bias'.

\section{Dealing with missing data}

Analyses were planned for the primary categorical outcome measures with five potential scenarios to the intention-to-treat analyses as able from the available published and author supplemented data (Hollis 1999). These scenarios are described in the Cochrane Hepato-Biliary Group Module (Gluud 2011) and are defined as the following:

- Carry-forward analysis: for all participants with missing data, regardless of group, the last reported observed response will be used.

- Poor outcome analysis: assumes that all of the participants with missing data (from either group) had the outcome of interest.
- Good outcome analysis: assumes that none of the participants with missing data (from either group) had the outcome of interest.

- Extreme-case favouring antibiotic therapy: assumes that none of the participants with missing data from the antibiotic group had the outcome of interest, whereas all of those from the control group had the outcome of interest.

- Extreme-case favouring control: assumes that all of the participants with missing data from the antibiotic group had the outcome of interest, whereas none from the control group had the outcome of interest.

\section{Assessment of heterogeneity}

Heterogeneity was assessed using the Chi-square test and I-square statistic.

\section{Data synthesis}

We attempted to assess each outcome on an intention-to-treat basis, though some trials failed to report the necessary data for this. Trial context and methods were assessed to determine if pooling of their data was appropriate.

We used Cochrane's Review Manager 5.1 software (RevMan 2011) to calculate individual trial estimates where appropriate generate meta-analyses of trials' estimates of effect as well as to perform stability analysis when indicated. When pooling of data was appropriate, we performed both fixed-effect and random-effects modelling. We reported the fixed-effect result when there was no difference between them. Otherwise, we reported both results. Trials that assessed an antibiotic against placebo were analysed separately from trials that assessed one antibiotic regimen with another one.

\section{Subgroup analysis and investigation of heterogeneity}

Two subgroup categorisations appeared relevant after initial evaluation of included trials: severe versus not-severe leptospirosis and troops or travellers versus endemic populations. However, these subgroups when sufficiently distinguishable did not overlap substantively providing data (events) to inform trial objectives.

Where considerable heterogeneity was present $(12>50 \%)$, we evaluated trial differences such as patient population and trial definitions.

\section{Sensitivity analysis}

We performed sensitivity analyses for pre-defined outcomes when sufficient applicable trials were available.

Pre-planned analyses were (but ultimately not relevant in this review because of a lack of overlap of outcomes for analysis and subgroup):

- Trials with low risk of bias compared to trials with high risk of bias.

- By presence of adequate methodological components compared with unclear or inadequate components.

- By presence or absence of blinding.

- By presentation forum (abstracts versus peer-reviewed journal).

- By specificity of inclusion criteria. 
- Iterative removal of trials from the meta-analysis to isolate sources of heterogeneity.

- Given sufficient number of selected trials (more than 10), we planned to perform funnel plot asymmetry analysis of trial size against antibiotic treatment in order to assess small-trial effects suggesting bias (Egger 1997).

\section{RESULTS}

\section{Description of studies}

Results of the search

Record yields from each of the components of the search strategy and subsequent vetting of results is delineated in Figure 1. 
Figure 1. Study flow diagram.

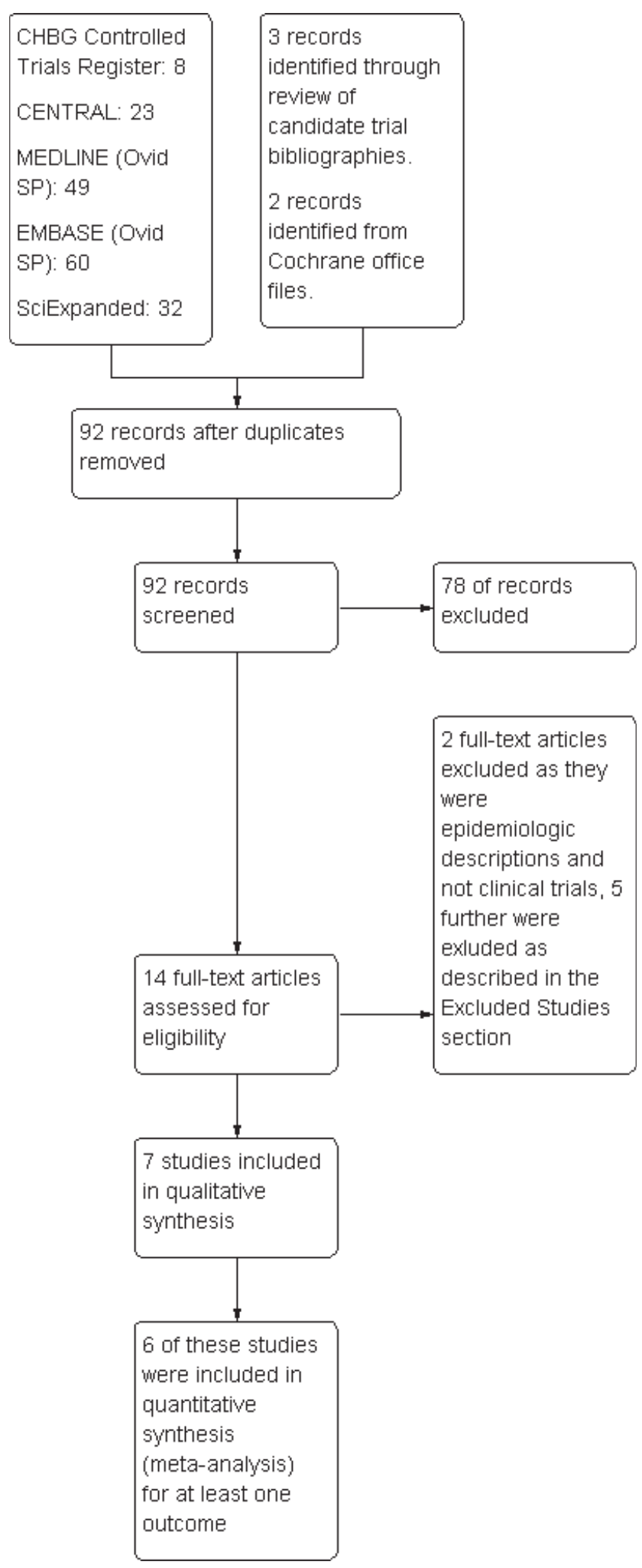




\section{Included studies}

Seven trials met inclusion criteria and were incorporated (Characteristics of included studies). Four of these were from the last decade and three from the 1980s. One of the trials evaluated troops in a training area while the others assessed interventions in resident populations.

\section{Excluded studies}

Five studies were excluded. Their details are provided (Characteristics of excluded studies). Reasons for exclusion ranged from use of retrospective data and mixed infections to no disclosure of definition for a patient's disease. Four of the five excluded studies were from the 1950s. Two studies provided information relevant to adverse events of therapy. Their contributions are discussed in that section.

\section{Risk of bias in included studies}

A determination of unclear bias was more common in older rather than newer trials. The presence of sufficient evidence to identify high risk of bias was present most frequently related to blinding. Specific comments on risk of bias are provided (Characteristics of included studies), as is a summary of study performance with regards to bias (Figure 2; Figure 3). Each of the seven included trials were at unclear or high risk for at least one bias domain and thus they fell into the group of trials with high risk of bias.

Figure 2. Risk of bias graph: review authors' judgements about each risk of bias item presented as percentages across all included studies.

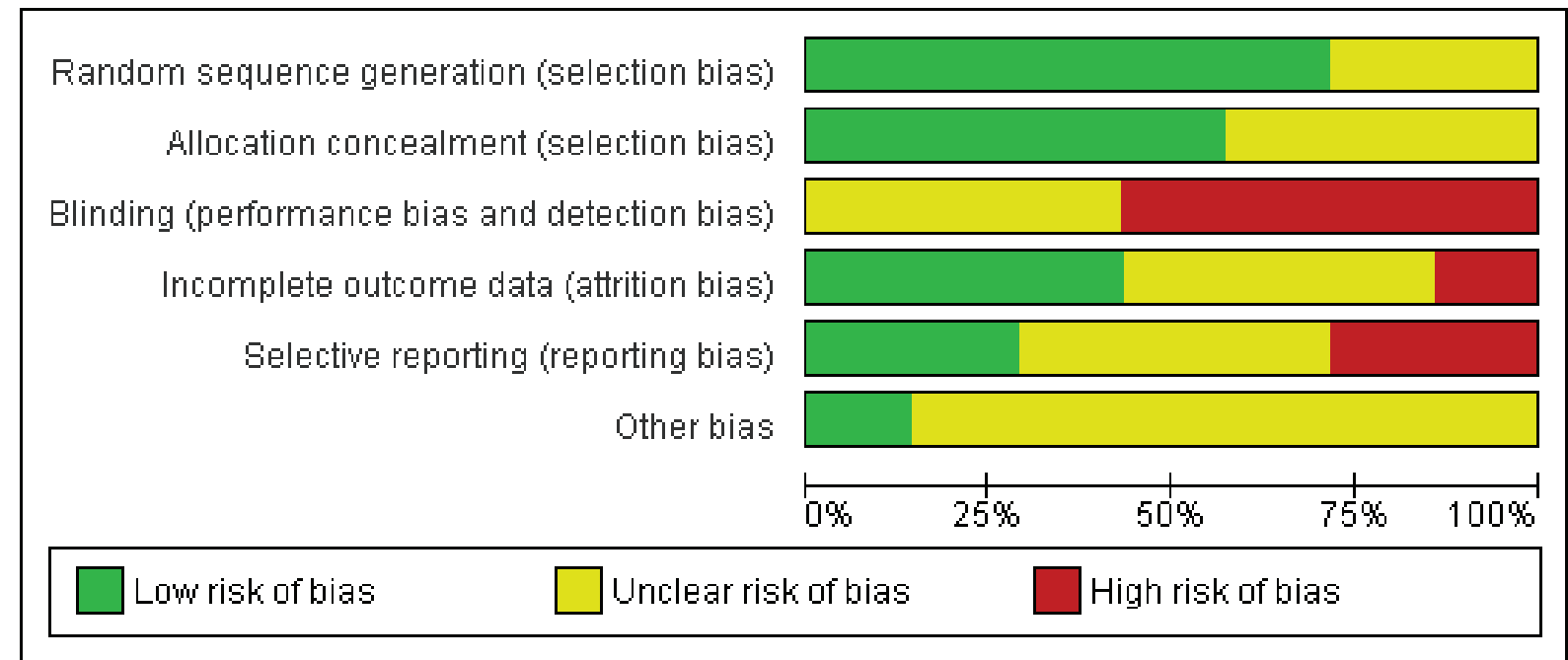


Figure 3. Risk of bias summary: review authors' judgements about each risk of bias item for each included study.

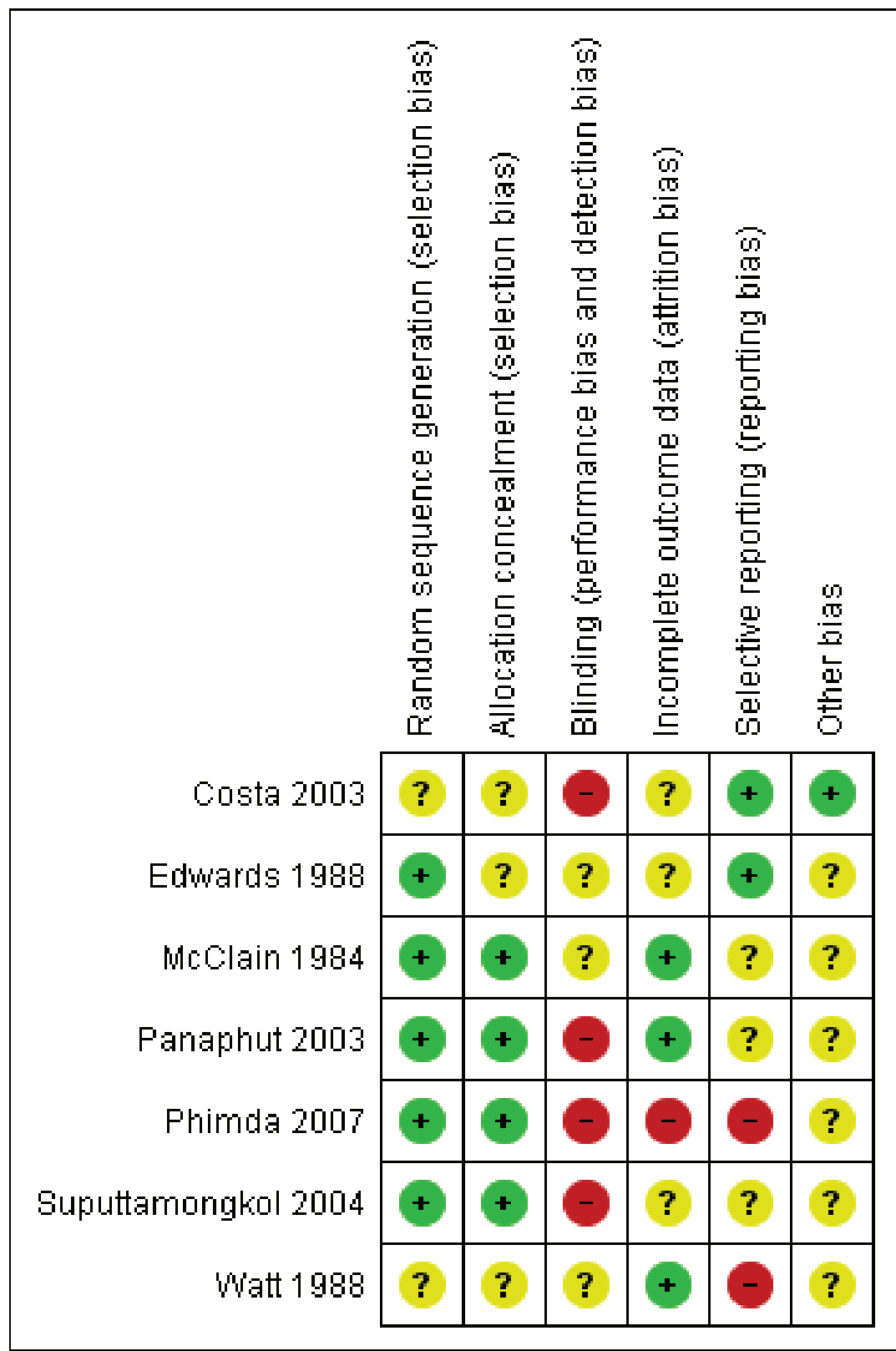

One trial excluded three patients for problems obtaining post discharge following (Suputtamongkol 2004), one patient in the cefotaxime group and two in the penicillin group. Data for death are given in the text under both the poor outcome scenario (which also is the extreme case scenario favouring doxycycline against penicillin and cefotaxime) and good outcome scenario (which also is the extreme case scenario favouring penicillin and cefotaxime against doxycycline). Data in the figures and tables reflect the poor outcome scenario. They were not considered for other outcomes. Carry forward analysis was not relevant to this situation.

\section{Allocation}

Generation of allocation sequence was described adequately in five trials and allocation concealment adequately in four out of the seven included trials.

\section{Blinding}

All seven included trials were either at high or unclear risk for bias related to blinding. Blinding methodology either was not reported or not performed across trials. 


\section{Incomplete outcome data}

Attrition was well delineated or minimised in three of the seven trials. In the single trial assessing azithromycin versus doxycycline for the treatment of leptospirosis, nearly a third of randomised patients were either not able to be assessed for post-discharge outcome or unable to be categorised as having leptospirosis or scrub typhus, or neither due to lack of suitable convalescent sera (Phimda 2007). Carry-forward analysis was not employed, however, the other four scenarios for dealing with missing data are represented with their relevant results.

\section{Selective reporting}

Two out of seven of the trials robustly reported on relevant outcomes (Costa 2003; Panaphut 2003) while in the other trials it was less clear but possible that all intended observations were reported.

\section{Other potential sources of bias}

Only one trial was demonstrably free of academic and funding biases (Costa 2003).

\section{Effects of interventions}

Five main comparator groups existed among included trials: antibiotics compared with placebo; cephalosporin compared with penicillin; doxycycline compared with penicillin; azithromycin compared with doxycycline; cephalosporin compared with doxycycline. Inclusion criteria for these trials required laboratory confirmation of leptospirosis, though the laboratory definition varied. Low number of outcomes and qualitative vice quantitative description of ventilator and dialysis requirements prevented assessment of the impact of therapy on these primary outcomes. None of the trials assessed attempted to intervene on hospitalisation through antimicrobial therapy.

\section{Antibiotics versus placebo}

While all four trials that compared antibiotics with placebo did report mortality (McClain 1984; Edwards 1988; Watt 1988; Costa 2003), there were no deaths in two of them (McClain 1984; Watt 1988). Since odds ratio calculations cannot employ zero-event trials, only two trials contributed to this estimate (Edwards 1988; Costa 2003). The calculated fixed-effect OR $(1.56,95 \% \mathrm{Cl} 0.70$ to 3.46) (Analysis 1.1), while not achieving statistical significance, is in the direction that favours placebo (skewed rightward). However, the estimate is driven by the larger trial (Costa 2003), and the directions of effect in the two trials are opposite. Consistent with this, the random-effects OR $(1.16 ; 95 \% \mathrm{Cl} 0.23$ to 5.95$)$ is smaller and less skewed. The heterogeneity suggested by this randomeffects and fixed-effect difference had an $1^{2}$ of $50 \%$ though as event count was low in Edwards 1988; this under-represents the differences between the two trials regarding mortality. In contrast to Costa 2003, the experimental penicillin group in Edwards 1988 was favoured with 1 versus 3 deaths though it did not reach statistical significance.

Only one trial reported days of hospitalisation without significant effect (8.9 versus 8.8 days) (MD 0.10 days, $95 \% \mathrm{Cl}-0.83$ to 1.03) (Analysis 1.2) (Costa 2003). Days of clinical illness were decreased incorporating data from two of the trials (McClain 1984; Watt 1988). This reached statistical significance under fixedeffect modelling; however, under random-effects modelling, the statistical significance was lost (fixed-effect: MD -2.13 days, 95\% $\mathrm{Cl}-2.46$ to -1.80 ; random-effects: MD -4.04 days, $95 \% \mathrm{Cl}-8.66$ to 0.58) (Analysis 1.3). $1^{2}$ for ratio of true heterogeneity in the outcome days of clinical illness was high (81\%). The two incorporated trials varied in several ways. One included presumably immune troops in a carefully monitored setting, while the other assessed relatively severe disease among an endemic population.There was no difference in days of fever (MD $0.30,95 \% \mathrm{Cl}-1.26$ to 1.86) (Analysis 1.5) (Edwards 1988). Three trials reported that therapy markedly decreased subsequent isolation of leptospires from urine, though sufficient data were not available to incorporate this outcome in our analysis (McClain 1984; Edwards 1988; Watt 1988).

\section{Cephalosporin versus penicillin}

This comparison was explored in two trials (Panaphut 2003; Suputtamongkol 2004). Death and days of fever were assessable across the trials, though for both outcomes the size of the estimate of effect was small and did not reach statistical significance (MD -0.03 days, $95 \% \mathrm{Cl}-0.09$ to 0.03 ) (Analysis 2.2).

Results for death did not vary substantively with missing data analysis (poor outcome scenario: OR $0.65,95 \% \mathrm{Cl} 0.23$ to 1.87 ; good outcome scenario: OR $0.72,95 \% \mathrm{Cl} 0.23$ to 2.21 ; extreme case scenario favouring cephalosporin: OR $0.56,95 \% \mathrm{Cl} 0.19$ to 1.64 ; extreme case scenario favouring penicillin: OR $0.84,95 \% \mathrm{Cl} 0.28$ to 2.58) (Analysis 2.1). While 12 was low in the analysis of death representing a low risk for heterogeneity, risk was high for days of fever with an 12 of $94 \%$.

While both of these trials explored severe leptospirosis, their definitions of such as well as their populations differed. Pooling of these results may not be valid.

\section{Doxycycline versus penicillin}

This comparison was explored ina single trial (Suputtamongkol 2004). There was no appreciable difference in either death (poor outcome scenario: OR $0.54,95 \% \mathrm{Cl} 0.10$ to 3.02 ; good outcome scenario: OR $1.10,95 \% \mathrm{Cl} 0.15$ to 8.00 ) (Analysis 3.1) or days of fever within this trial (MD 0.00 days, $95 \% \mathrm{Cl}-0.25$ to 0.25 ) (Analysis 3.2).

\section{Azithromycin versus doxycycline}

This comparison also was explored in a single trial (Phimda 2007). Among the subset of patients who had confirmed leptospirosis time to defervescence was not significantly different between the two groups, median 45 hours (range 8 to 118) in the doxycycline group, 40 hours (range 8 to 136) in the azithromycin group. Data were not available to analyse mean difference. The authors reported the fraction of participants with leptospirosis who became afebrile within 48 hours of initiation of therapy (Analysis 4.1). Odds of becoming afebrile quickly were similar in the two intervention groups (OR 1.51, 95\% Cl 0.57 to 4.00). Severe outcomes were not observed.

\section{Cephalosporin versus doxycycline}

This comparison was explored in a single trial (Suputtamongkol 2004). There was no appreciable difference in death (poor outcome scenario: OR $0.45,95 \% \mathrm{Cl} 0.04$ to 5.1 ; good outcome scenario: OR $0.18,95 \% \mathrm{Cl} 0.01$ to 3.80 ) (Analysis 5.1).

\section{Adverse events}

No adverse events were reported as attributed to cephalosporin therapy. In the discussion of Costa 2003, the authors commented 
that $4 \%$ of patients who died did so in the first three days of their enrolment with a trend towards earlier death when it did occur in the group receiving penicillin. As above noted, the trend for increased death in the intervention group did not reach statistical significance and was diminished when incorporating randomeffects modelling in the setting of study heterogeneity. This was the only trial to report dialysis rates, a pre-defined primary outcome of interest in this review. Again, statistical significance was not reached, but in that trial the estimate of effect favoured the placebo group with regards to need for dialysis. The baseline characteristics table in that trial revealed a differential rate of severe renal failure with serum creatinine levels greater than $3 \mathrm{mg} / \mathrm{dL}$ (approximately $265 \mu \mathrm{mol} / \mathrm{L}$ ) in $33 \%$ of patients in the penicillin group and $28 \%$ of patients in the placebo group. It was not possible from the available data to assess whether risk of dialysis explained the trend towards increased death nor to appreciate to what extent this 5\% difference in initial renal involvement explained the trend towards dialysis. Edwards 1988 et al reported that they employed an early peritoneal dialysis strategy in renal failure within their trial. Consequently, their data was included in the analysis with Costa 2003 (Analysis 1.4). Heterogeneity between these two studies was low for this outcome, $1^{2}$ of 0 and a result tending to favour the control group (OR $1.54,95 \% \mathrm{Cl} 0.91$ to 2.60 ). Due to the possibility that the professed Edwards 1988 early dialysis strategy was unevenly applied, missing data analysis favouring the extreme case scenarios were employed to test the potential impact on their trial. In neither case was statistical significance achieved (extreme case favouring penicillin: OR $0.39,95 \% \mathrm{Cl} 0.01$ to $14.86, \mathrm{I}^{2} 84 \%$ (used randomeffects modelling); extreme case favouring control: OR 3.92, 95\% $\mathrm{Cl} 0.40$ to $38.43 ; \mathrm{I}^{2}$ 63\% (used random-effects modelling)). One excluded trial asserted that no difference was present in frequency or severity of renal injury in treated as compared with untreated patients (Hall 1951), though it investigated a heterogenous group of therapies. Edwards 1988 reported a single Jarisch-Herxheimer reaction in a patient three hours after administration of penicillin. This trial also reported iritis though it occurred in two instances in the placebo group and in only one instance in the therapy group.

A trial of azithromycin versus doxycycline for treatment of all comers suspected of either leptospirosis or scrub typhus demonstrated two cessations of therapy for adverse events in the doxycycline group (one patient with rash and the other with severe vomiting), but none in the azithromycin group (Phimda 2007). Proportions of adverse events also were higher in the doxycycline group, occurring in $28 \%$ versus $11 \%$ of patients. Thirtyseven of the 40 events in the doxycycline group were mild to moderate gastrointestinal complaints, while one complaint of rash in the doxycycline group and two in the azithromycin group were reported. Two events of dizziness were reported only in the doxycycline group. The trial by Phimda 2007 et al did not contribute information related to dialysis requirements. An included trial also assessed gastrointestinal complaints related to doxycycline (McClain 1984). No cessations of therapy due to adverse events were reported by McClain 1984 et al. While the trial did not provide comparative proportions of adverse events, it reported mean duration of gastrointestinal complaints among enrollees in both groups of the trial. Those in the placebo group reported a mean $2.1+/-0.5$ days of gastrointestinal upset in contrast to $1.1+/$ 0.3 days in the doxycycline group.

\section{DISCUSSION}

\section{Summary of main results}

The only result to achieve statistical significance (valid estimate of effect across its $95 \% \mathrm{Cl}$ or $\mathrm{P}<0.05$ ), approximately a two-day reduction in the number of days of clinical illness amongst patients on antibiotic therapy in contrast with placebo, lost statistical significance when assessed with random-effects modelling indicated by the apparent study heterogeneity. The effect may be greater for severe disease. Neither a choice of antibiotics versus placebo nor cephalosporin versus penicillin statistically significantly impacted patient mortality. Differences in assessable outcomes between different antibiotic choices were small. Some authors asserted that earlier therapy resulted in improved results, but supporting data were not reported.

Doxycycline-associated gastrointestinal complaints dominated the adverse events in a single excluded study. While this was not mirrored in the relevant included trials, it is consistent with findings on a review of antibiotic use for prophylaxis against leptospirosis (Brett-Major 2009). Dialysis was more common among penicillin recipients than those who received placebo (Costa 2003; Edwards 1988). The result did not reach statistical significance. While some authors argue that a threshold of $\mathrm{P}<0.1$ may be more appropriate in this type of analysis in order to account for the effect of unreported data and publication bias on sensitivity (Leandro 2005), the $P$ value for this analysis result was 0.11 and the convention remains $P<0.05$. Additionally, this finding may be confounded by an increased proportion of baseline severe renal dysfunction in the penicillin group (Costa 2003).

\section{Overall completeness and applicability of evidence}

Multiple databases without language restrictions were explored in the generation of this review. While an explicit test for publication bias was relevant only for the outcome days of clinical illness for antibiotics versus placebo, it was inconclusive.

Several interesting observational studies and clinical trials have been executed on the treatment of leptospirosis over the past 60 years. Nonetheless, the breadth of literature remains pleomorphic. Four of the seven included trials in this review purported to assess therapy in severe leptospirosis. However, in most cases clear definitions of severity were not provided and the most severe presenting patients - those with anuria, obtundation - excluded. In one trial, roughly $90 \%$ of patients exhibited jaundice at baseline while severe renal failure was present in $33 \%$ and $28 \%$ of the penicillin and placebo groups, respectively, with more mild renal failure present in over $90 \%$ (Costa 2003). Another trial reported baseline jaundice in $43 \%$ and $47 \%$ of the cephalosporin and penicillin groups, respectively, and approximately $80 \%$ with some renal failure in both groups (Panaphut 2003). Some renal failure was present in 41\%, 28\%, 40\% of the penicillin, doxycycline, cefotaxime groups with $32 \%, 25 \%$, and $35 \%$ prevalences of jaundice, respectively (Suputtamongkol 2004). In this trial doxycycline was favoured with patients of lower severity of illness against other antibiotic selections. These three trials with Edwards 1988 contributed all of the mortality events. The trial of troops did not seem to have significant baseline severity though it was not detailed in the report (McClain 1984). Duration of illness at presentation also varied across trials. Though, one trial had a high rate of exclusion due to death within 24 hours and 
another reported that most patients had more than five days of symptoms, both suggesting later disease (Watt 1988; Costa 2003).

Despite a lack of evidence of the utility of antibiotic therapy for leptospirosis, penicillin, cephalosporins, and doxycycline are commonly employed therapies in the management of leptospirosis. Despite its higher cost, interest in azithromycin against Leptosira spp. is increasing due to its broad activity against confounding pathogens, low mean inhibitory concentration (MIC), and fewer mild adverse events (Phimda 2007; Ressner 2008).

Penicillin has been tested against placebo for the treatment of severe leptospirosis. However, benefits were uneven across the patient populations and the nature of adverse events from therapy in severe disease is not clear. This makes a robust risk-benefit analysis difficult. Further placebo controlled trials are needed.

\section{Quality of the evidence}

The potential for bias in the trials was high and may reflect the long period of time across which both the included and excluded trials were conducted, consequently the literature practices of their times. The most problematic issues were blinding and disclosure of the roles of commercial partners. Blinding was particularly difficult to accomplish in these trials because antibacterial agents against gram negative pathogens were available to treatment teams when not employing a cephalosporin for the trial intervention. The lack of a placebo for these anti-gram negative pathogen agents such as gentamicin increased variability in the trials and possibly introduced confounding, though use was generally well distributed between groups. The potential for misclassification of patients during intake into these types of trials is high. Edwards 1988, for instance, used clinical criteria for dengue as an exclusion criteria. However, clinical confusion between leptospirosis and dengue can be high (LaRocque 2005).

\section{Potential biases in the review process}

Random errors are particularly problematic in reviews in which few trials are contributing events to individual outcomes. Only one author of two of the trials responded to this review when a draft of this manuscript was sent 15 May 2011, Dr. Yupin Suputtamongkol. His clarification was very helpful for two of the reviewed trials (Suputtamongkol 2004; Phimda 2007). While only three additional candidate references were identified on serial electronic literature searches between initiation and repeat of the search, some relevant pre-MEDLINE studies later excluded were identified only by bibliographic or hard copy Cochrane Hepato-Biliary Group file review. As in any such review, relevant literature might have been missed. Publication bias towards those trials which show affirmative results is a well recognised concern. However, several negative trials for most outcomes were present in both the included and excluded trials.

\section{Agreements and disagreements with other studies or reviews}

The breadth of available data has evolved since the previous iteration of this review (Costa 2003; Panaphut 2003; Suputtamongkol 2004; Phimda 2007). That review identified 12 relevant records meriting full-text evaluation and incorporated five trials (Guidugli 2000). Like the earlier review, this review did not reveal evidence compelling the use of antibiotic therapy for leptospirosis.

\section{AUTHORS' CONCLUSIONS}

\section{Implications for practice}

Insufficient evidence is available to advocate for or against the use of antibiotics in the therapy for leptospirosis. Among survivors who were hospitalised for leptospirosis, use of antibiotics for leptospirosis may have decreased the duration of clinical illness by two to four days though this result was not statistically significant. Relatively severe and possibly late leptospirosis patients may have increased dialysis when penicillin is used rather than placebo, but this result was driven by a single trial, the estimate of effect was small and it did not reach statistical significance. If a clinician chooses to utilize antibiotic therapy, there is no evidence to suggest that selection of penicillin, doxycycline, or cephalosporin impacts mortality or duration of fever.

\section{Implications for research}

Further placebo controlled trials exploring antibiotic therapy for carefully staged leptospirosis is needed. The question of whether or not antibiotics should be used in leptospirosis remains open, as does the optimal timing and severity in which to employ such therapy. Potential trials could include a wider array of tested agents tried against placebo for therapy against leptospirosis. Careful planning in such trials should be done for disease severity, targeted outcomes such as minimisation of lost work days, prevention of hospitalisation, dialysis, and in areas where pulmonary manifestations are dominant, ventilation as well as death. If antibiotics confer true risk in leptospirosis therapy, their assessment might include factorial research designs which simultaneously assess adjunctive therapies which might mitigate their effect. In the future, trials ought to be conducted with less risk of systematic errors (bias) and less risk of random errors (play of chance) and ought to be reported according to the CONSORT guidelines (www.consort-statement.org).

\section{ACKNOWLEDGEMENTS}

We thank the authors of the previous Cochrane review on this topic for their work assessing the available literature on antibiotic therapy for leptospirosis - F Guidugli, AA Castro, and AN Atallah. Support from the Cochrane Hepato-Bilary Group remains outstanding from both the Trials Search Co-ordinator, Ms. Sarah Klingenberg, and Dimitrinka Nikolova, Managing Editor.

Protocol

Peer Reviewers: Vanja Giljaca, Croatia; Goran Poropat, Croatia. Contact Editor: Christian Gluud, Denmark.

Review

Peer Reviewers: Vanja Giljaca, Croatia; Goran Poropat, Croatia. Contact Editor: Ronald Koretz, United States; Christian Gluud, Denmark. 


\section{R E F E R E N C E S}

\section{References to studies included in this review}

Costa 2003 \{published data only (unpublished sought but not used)\}

* Costa E, Lopes AA, Sacramento E, Costa YA, Matos ED, Baretto M, et al. Penicillin at the late stage of leptospirosis: a randomized controlled trial. Revista do Instituto de Medicina Tropical de Sao Paulo 2003;45(3):141-5.

Edwards 1988 \{published data only\}

* Edwards CN, Nicholson GD, Hassell TA, Everard CO, Callender J. Penicillin therapy in icteric leptospirosis. American Journal of Tropical Medicine and Hygiene 1988;39(4):388-90.

McClain 1984 \{published data only\}

* McClain BL, Ballou WR, Harrison SM, Steinweg DL. Doxcycyline therapy for leptospirosis.. Annals of Internal Medicine 1984;100(5):696-8.

Panaphut 2003 \{published data only (unpublished sought but not used)\}

* Panaphut T, Domrongkitchaiporn S, Vibhagool A Thinkamrop B, Susaengrat W. Ceftriaxone compared with sodium penicillin for treatment of severe leptospirosis. Clinical Infectious Diseases 2003;36:1507-13.

\section{Phimda 2007 \{published and unpublished data\}}

* Phimda K, Hoontrakul S, Suttinont C, Chareonwat S, Losuwanaluk K, Chueasuwanchai S, et al. Doxycycline versus azithromycin for treatment of leptospirosis and scrub typhus. Antimicrobial Agents and Chemotherapy 2007;51(9):3259-63.

Suputtamongkol 2004 \{published and unpublished data\}

* Suputtamongkol Y, Niwattayakul K, Suttinont C, Losuwanaluk K, Limpaiboon R, Chierakul W, et al. An open, randomized, controlled trial of penicillin, doxycycline, and cefotaxime for patients with severe leptospirosis. Clinical Infectious Diseases 2004;39:1417-24.

Watt 1988 \{published data only\}

* Watt G, Padre LP, Tuazon ML, Calubaquib C, Santiago E, Ranoa CP, et al. Placebo-controlled trial of intravenous penicillin for severe and late leptospirosis. Lancet 1988;1(8583):433-5.

\section{References to studies excluded from this review}

Doherty 1955 \{published data only\}

Doherty RL. A clinical study of leptospirosis in North Queensland. Australas Annals of Medicine 1955;4(1):53-63.

Fairburn 1956 \{published data only\}

Fairburn AC, Semple SJG. Chloramphenicol and penicillin in the treatment of leptospirosis among British troops in Malaya. Lancet 1956;270(6906):13-6.
Hall 1951 \{published data only\}

Hall HE, Hightower JA, Diaz Rivera R, Byrne RJ, Smadel JE, Woodward TE. Evaluation of antibiotic therapy in human leptospirosis. Annals of Internal Medicine 1951;35(5):981-98.

Munnich 1972 \{published data only\}

Munnich D, Lakatos M. Treatment of leptospirosis with Semicillin. Therapia Hungarica (English Edition) 1972;20(4):152-5.

Russell 1958 \{published data only\}

Russell RW. Treatment of leptospirosis with oxytetracycline. Lancet 1958;2(7057):1143-5.

\section{Additional references}

\section{Bharti 2003}

Bharti AR, Nally JE, Ricaldi JN, Matthias MA, Diaz MM, Lovett MA, et al. Leptospirosis: a zoonotic disease of global importance. The Lancet Infectious Diseases 2003;3(12):757-71.

\section{Brett-Major 2009}

Brett-Major DM, Lipnick RJ. Antibiotic prophylaxis for leptospirosis. Cochrane Database of Systematic Reviews 2009, Issue 3. [DOI: 10.1002/14651858.CD007342.pub2]

\section{Egger 1997}

Egger M, Davey Smith G, Schneider M, Minder C. Bias in metaanalysis detected by a simple, graphical test. BMJ (Clinical Research Ed.) 1997;315:629-34.

\section{Gluud 2011}

Gluud C, Nikolova D, Klingenberg SL, Whitfield K, Alexakis N, Als-Nielsen B, et al. Cochrane Hepato-Biliary Group. About The Cochrane Collaboration (Cochrane Review Groups (CRGs)). 2011, Issue 8. Art. No.: LIVER.

\section{Hadad 2006}

Hadad E, Pirogovsky A, Bartal C, Gilad J, Barnea A, Yitzhaki S, et al. An outbreak of leptospirosis among Israeli troops near the Jordan River. The American Journal of Tropical Medicine and Hygiene 2006;74(1):127-31.

\section{Higgins 2011}

Higgins JPT, Green S (editors). Cochrane Handbook for Systematic Reviews of Interventions Version 5.1.0 [updated March 2011]. The Cochrane Collaboration, 2011. Available from www.cochrane-handbook.org.

\section{Hollis 1999}

Hollis S, Campbell F. What is meant by intention to treat analysis? Survey of published randomised controlled trials. BMJ (Clinical Research Ed.) 1999;319:670-4.

\section{ICH-E3 1995}

$\mathrm{ICH}$ harmonized tripartite guideline. Guideline on structure and content of clinical study reports (E3). Geneva: International Conference on Harmonization of Technical Requirements 
for Registration of Pharmaceuticals for Human Use. http:// www.ich.org/fileadmin/Public_Web_Site/ICH_Products/ Guidelines/Efficacy/E3/Step4/E3_Guideline.pdf 1995 (accessed 16 May 2011).

\section{ICH-GCP 1996}

$\mathrm{ICH}$ harmonised tripartite guideline. Guideline for good clinical practice E6 (R1). Geneva: International Conference on Harmonisation of Technical Requirements for Registration of Pharmaceuticals for Human Use. http://www.ich.org/fileadmin/ Public_Web_Site/ICH_Products/Guidelines/Efficacy/E6_R1/ Step4/E6_R1__Guideline.pdf 1996 (accessed 16 May 2011).

\section{Kjaergard 2001}

Kjaergard LL, Villumsen J, Gluud C. Reported methodologic quality and discrepancies between large and small randomized trials in meta-analyses. Annals of Internal Medicine 2001;135:982-9.

\section{LaRocque 2005}

LaRocque RC, Breiman RF, Ari MD, Morey RE, Janan FA, Hayes JM, et al. Leptospirosis during dengue outbreak, Bangladesh. Emerging Infectious Diseases 2005;11(5):766-9.

\section{Leandro 2005}

Leangro G. Meta-analysis in Medical Research: The Handbook for the Understanding and Practice of Meta-Analysis. Oxford: Blackwell Publishing Ltd., 2005.

\section{Liverpool 2008}

Liverpool J, Francis S, Liverpool CE, Dean GT, Mendez DD. Leptospirosis: case reports of an outbreak in Guyana. Annals of Tropical Medicine and Parasitology 2008;102(3):239-45.

\section{Moher 1998}

Moher D, Pham B, Jones A, Cook DJ, Jadad AR, Moher M, et al. Does quality of reports of randomised trials affect estimates of intervention efficacy reported in meta-analyses?. Lancet 1998;352:609-13.

\section{Pappas 2008}

Pappas G, Papadimitriou P, Siozopoulo V, Christou L, Akritidis N. The globalization of leptospirosis: worldwide incidence trends. International Journal of Infectious Diseases 2008;12(4):351-7. [MEDLINE: 18055245]

\section{Ressner 2008}

Ressner RA, Griffith ME, Beckius ML, Pimentel G, Miller RS, Mende K, et al. Antimicrobial susceptibilities of geographically diverse clinical human isolates of Leptospira. Antimicrobial Agents and Chemotherapy 2008;52(8):2750-4.

\section{CHARACTERISTICS OF STUDIES}

Characteristics of included studies [ordered by study ID]

\section{RevMan 2011 [Computer program]}

The Nordic Cochrane Centre, The Cochrane Collaboration. Review Manager (RevMan). Version 5.1. Copenhagen: The Nordic Cochrane Centre, The Cochrane Collaboration, 2011.

\section{Royle 2003}

Royle P, Milne R. Literature searching for randomized controlled trials used in Cochrane reviews: rapid versus exhaustive searches. International Journal of Technology Assessment in Health Care 2003;19(4):591-603.

\section{Russell 2003}

Russell KL, Montiel Gonzalez MA, Watts DM, Lagos-Figueroa RC, Chauca G, Ore M, et al. An outbreak of leptospirosis among Peruvian military recruits. The American Journal of Tropical Medicine and Hygiene 2003;69(1):53-7.

\section{Schulz 1995}

Schulz KF, Chalmers I, Hayes RJ, Altman DG. Empirical evidence of bias. Dimensions of methodological quality associated with estimates of treatment effects in controlled trials. JAMA 1995;273:408-12.

\section{Sejvar 2003}

Sejvar J, Bancroft E, Winthrop K, Bettinger J, Bajani M, Bragg S, et al. Leptospirosis in "Eco-Challenge" athletes, Malaysian Borneo, 2000. Emerging Infectious Diseases 2003;9(6):702-7.

\section{WHO 2003}

World Health Organization. International Leptospirsos Society. Human Leptospirosis: Guide for Diagnosis, Surveillance and Control. World Health Organization, 2003.

\section{Wood 2008}

Wood L, Egger M, Gluud LL, Schulz KF, Jüni P, Altman DG, et al. Empirical evidence of bias in treatment effect estimates in controlled trials with different interventions and outcomes: meta-epidemiological study. BMJ (Clinical Research Ed.) 2008;336:601-5.

\section{References to other published versions of this review}

\section{Guidugli 2000}

Guidugli DF, Castro AA, Atallah AN. Antibiotics for treating leptospirosis. Cochrane Database of Systematic Reviews 2000, Issue 2. [DOI: 10.1002/14651858.CD001306]

* Indicates the major publication for the study

Costa 2003

Methods Prospective, single site, randomised, clinical trial. 
Costa 2003 (Continued)

Participants All comers to a regional hospital with four days of symptoms and a WHO leptospirosis score of at least 26, predominantly men in the 3rd to 5 th decade of life. 247 of 253 patients had a positive macroscopic slide agglutination test for leptospirosis, 45 a micro-agglutination test (MAT) and 17 a positive blood culture for Leptospira.

Interventions PCN 1 million units parentally every four hours for seven days against no targeted antimicrobial therapy.

\begin{tabular}{ll}
\hline Outcomes & Death, length of hospitalisation, and dialysis. \\
\hline Notes & $\begin{array}{l}\text { Approximately } 94 \% \text { of their patients in both groups had icterus suggesting that this represented a trial } \\
\text { of therapeutic efficacy in late disease. Multiple biomarkers were collected at days } 0,3 \text {, and } 7 \text { from ad- } \\
\text { mission. Authors reported no difference between groups but did not discuss changes over time. }\end{array}$
\end{tabular}

\section{Risk of bias}

\begin{tabular}{|c|c|c|}
\hline Bias & Authors' judgement & Support for judgement \\
\hline $\begin{array}{l}\text { Random sequence genera- } \\
\text { tion (selection bias) }\end{array}$ & Unclear risk & $\begin{array}{l}\text { P 142, "each patient... and was randomly assigned to... ." though no descrip- } \\
\text { tion of method of randomisation to include sequence generation was provid- } \\
\text { ed. }\end{array}$ \\
\hline $\begin{array}{l}\text { Allocation concealment } \\
\text { (selection bias) }\end{array}$ & Unclear risk & Not discerned. \\
\hline $\begin{array}{l}\text { Blinding (performance } \\
\text { bias and detection bias) } \\
\text { All outcomes }\end{array}$ & High risk & $\begin{array}{l}\text { P } 143 \text {, "Even though in the present study the treating physicians were not blind } \\
\text { to the patient assignment" }\end{array}$ \\
\hline $\begin{array}{l}\text { Incomplete outcome data } \\
\text { (attrition bias) } \\
\text { All outcomes }\end{array}$ & Unclear risk & Not discerned. \\
\hline $\begin{array}{l}\text { Selective reporting (re- } \\
\text { porting bias) }\end{array}$ & Low risk & $\begin{array}{l}\text { P 143, Table } 2 \text { outcome data for death calculated for same numbers as shown } \\
\text { in Table } 1 \text { Demographics. }\end{array}$ \\
\hline Other bias & Low risk & P 144, trial executed using public grants. \\
\hline
\end{tabular}

\section{Edwards 1988}

\begin{tabular}{ll}
\hline Methods & Prospective, single site, randomised, clinical trial. \\
\hline Participants & $\begin{array}{l}\text { All comers for who there was a clinical suspicion of icteric leptospirosis later diagnosed through culture } \\
\text { or convalescent titer rise. They were predominantly men in the fourth decade of life. }\end{array}$ \\
\hline Interventions & 2 million units of intravenous penicillin every 6 hours for 5 days or saline. \\
\hline Outcomes & $\begin{array}{l}\text { Time to defervescence, clearance of urine culture, normalisation of laboratory values, renal failure, and } \\
\text { death. }\end{array}$ \\
\hline Notes & $\begin{array}{l}\text { This trial targeted severe leptospirosis. Serum biomarkers collected on admission had high standard } \\
\text { deviations though reportedly } 7 \text { of } 38 \text { and } 8 \text { of } 41 \text { patients in the penicillin and placebo groups, respec- } \\
\text { tively, had renal failure on admission. }\end{array}$
\end{tabular}

\section{Risk of bias}


Edwards 1988 (Continued)

\begin{tabular}{lll} 
Bias & Authors' judgement & Support for judgement \\
\hline $\begin{array}{l}\text { Random sequence genera- } \\
\text { tion (selection bias) }\end{array}$ & Low risk & $\begin{array}{l}\text { P 388, while the method of randomisation is not explicitly stated, authors ref- } \\
\text { erence a source with several approaches to randomisation. }\end{array}$ \\
\hline $\begin{array}{l}\text { Allocation concealment } \\
\text { (selection bias) }\end{array}$ & Unclear risk & Not discerned. \\
\hline $\begin{array}{l}\text { Blinding (performance } \\
\text { bias and detection bias) } \\
\text { All outcomes }\end{array}$ & Unclear risk & $\begin{array}{l}\text { P. 388, the trial used a saline placebo and stated that the investigator involved } \\
\text { in allocation was not involved in management, but there is no explicit mention } \\
\text { of blinding. }\end{array}$ \\
\hline
\end{tabular}

Incomplete outcome data Unclear risk Not discerned.

(attrition bias)

All outcomes

\begin{tabular}{ll}
\hline $\begin{array}{l}\text { Selective reporting (re- } \\
\text { porting bias) }\end{array}$ & Low risk \\
& $\begin{array}{l}\text { Death was reported. While renal failure and not dialysis was reported, authors } \\
\text { stated that they employed early peritoneal dialysis in renal failure so that as- } \\
\text { sertion applied in the dialysis analysis incorporating missing data outcome } \\
\text { scenarios. }\end{array}$
\end{tabular}

\begin{tabular}{ll}
\hline Other bias $\quad$ Unclear risk & Not discerned. \\
\hline
\end{tabular}

\section{McClain 1984}

\begin{tabular}{|c|c|c|}
\hline Methods & \multicolumn{2}{|c|}{ Prospective, single site, blinded, randomised, clinical trial. } \\
\hline Participants & \multicolumn{2}{|c|}{$\begin{array}{l}\text { Troops presenting for care with fever and subsequent verified leptospirosis serology or culture at the } \\
\text { Jungle Operations Training Center, Panama. } 26 \text { of } 29 \text { patients had positive blood cultures for Leptospi- } \\
\text { ra. }\end{array}$} \\
\hline Interventions & \multicolumn{2}{|c|}{ Seven day course of twice daily doxycyline hyclate $100 \mathrm{mg}$ or placebo. } \\
\hline Outcomes & \multicolumn{2}{|c|}{ Assessed clearing of cultures and resolution of fever. } \\
\hline Notes & \multicolumn{2}{|c|}{ This trial evaluated therapeutic efficacy in early disease. } \\
\hline \multicolumn{3}{|l|}{ Risk of bias } \\
\hline Bias & Authors' judgement & Support for judgement \\
\hline $\begin{array}{l}\text { Random sequence genera- } \\
\text { tion (selection bias) }\end{array}$ & Low risk & $\begin{array}{l}\text { P. } 697, \text { "packets were randomly assigned by computer to contain doxycycline } \\
\text { hyclate or lactose" }\end{array}$ \\
\hline $\begin{array}{l}\text { Allocation concealment } \\
\text { (selection bias) }\end{array}$ & Low risk & $\begin{array}{l}\text { P. } 696 \text {, "assigned sequentially numbered packets of tablets that were identical } \\
\text { in appearance" }\end{array}$ \\
\hline $\begin{array}{l}\text { Blinding (performance } \\
\text { bias and detection bias) } \\
\text { All outcomes }\end{array}$ & Unclear risk & Not discerned. \\
\hline $\begin{array}{l}\text { Incomplete outcome data } \\
\text { (attrition bias) } \\
\text { All outcomes }\end{array}$ & Low risk & $\begin{array}{l}\text { P. } 697, \text { "after discharge, patients were followed every other day for } 1 \text { week and } \\
\text { once a week thereafter for } 2 \text { weeks" }\end{array}$ \\
\hline
\end{tabular}


McClain 1984 (Continued)

Selective reporting (reporting bias)

Unclear risk
Pre-defined study outcomes inconsistent with those listed in the Types of Outcomes section, though death did not occur and was discernible from the published data.

Other bias Unclear risk Not discerned.

\section{Panaphut 2003}

\begin{tabular}{ll} 
Methods & Prospective, single-site, randomised, comparative trial. \\
\hline Participants & $\begin{array}{l}\text { Adult patients presenting with severe leptospirosis, predominantly men in the 4th through } 6 \text { th decades } \\
\text { of life with an average WHO leptospirosis score } 23 \text { to } 24 . \text { Laboratory confirmation by titer or culture was } \\
\text { required for inclusion in analysis. All } 173 \text { had a positive rapid test for leptospirosis, only } 126 \text { were con- } \\
\text { firmed by MAT. }\end{array}$
\end{tabular}

Interventions

Antibiotics for seven days or until afebrile for 48 hours: ceftriaxone $1 \mathrm{gm}$ parenterally daily or penicillin 1.5 million units every 6 hours with the addition of gentamicin if also suspicious for gram negative sepsis.

\begin{tabular}{ll}
\hline Outcomes & Death, duration of fever, and renal failure. \\
\hline Notes & All deaths occurred within five days of hospitalisation - 5 pulmonary haemorrhage, 2 multi-organ fail- \\
& ure, 1 severe hyperk, uraemic encephalopathy, 1 ARDS. However, causes are not delineated by treat- \\
& ment group. It is unclear for how long patients who received penicillin also received gentamicin. Those \\
& patients treated with ceftriaxone had higher rates of prior treatment with doxycycline and penicillin. \\
& Standard deviation on mean days of fever were not provided so substituted the range of absolute dif- \\
& ference.
\end{tabular}

\section{Risk of bias}

\begin{tabular}{lll}
\hline Bias & Authors' judgement & Support for judgement \\
\hline $\begin{array}{l}\text { Random sequence genera- } \\
\text { tion (selection bias) }\end{array}$ & Low risk & $\begin{array}{l}\text { P. 1508, "patients were randomly allocated into } 2 \text { groups by stratified-block } \\
\text { randomisation" }\end{array}$ \\
\hline $\begin{array}{l}\text { Allocation concealment } \\
\text { (selection bias) }\end{array}$ & Low risk & P. 1508, "each label was enclosed in a sealed, opaque envelope" \\
\hline $\begin{array}{l}\text { Blinding (performance } \\
\text { bias and detection bias) }\end{array}$ & High risk & $\begin{array}{l}\text { P. 1508, the ceftriaxone and penicillin groups had different medication admin- } \\
\text { istration regimens, each day versus four times daily. The addition of gentam- } \\
\text { icin among penicillin recipients when gram negative sepsis had not been ex- } \\
\text { cluded increased the likelihood that observers were aware of treatment allo- } \\
\text { cation. }\end{array}$ \\
\hline $\begin{array}{l}\text { Incomplete outcome data } \\
\text { (attrition bias) }\end{array}$ & Low risk & $\begin{array}{l}\text { p1509, causes for exclusion from the trial and analyses were clearly enumer- } \\
\text { ated. P 1509-10, "For those who did not return for follow-up after being dis- } \\
\text { charged from the hospital, data regarding their physical conditions after dis- } \\
\text { charge were obtained individually by direct contact of local health care per- } \\
\text { sonnel. All of the patients [who had not returned] completely recovered from } \\
\text { the illness." }\end{array}$ \\
\hline $\begin{array}{l}\text { Selective reporting (re- } \\
\text { porting bias) }\end{array}$ & Unclear risk & $\begin{array}{l}\text { P. 1510, "Ten patients (5 in each group) died, for an overall case mortality rate, } \\
5.8 \% " \text { which is correct for the number of patients reported to have been in- } \\
\text { cluded. While burden of renal failure was reported as was an overall dialysis } \\
\text { rate of more than 10 per cent, dialysis was not discernible in each trial arm. }\end{array}$ \\
\hline
\end{tabular}


Panaphut 2003 (Continued)

Other bias Unclear risk P. 1507, Ceftriaxone was provided by Siam Pharmaceutical. No statement regarding the role of funding agents was provided.

Phimda 2007

\begin{tabular}{|c|c|}
\hline Methods & Prospective, multi-site, randomised, clinical trial. \\
\hline Participants & $\begin{array}{l}\text { Patients over } 14 \text { years of age with suspected leptospirosis or scrub typhus as described by acute fever } \\
\text { without clear source of infection and able to tolerate oral antibiotic therapy. Among all randomised pa- } \\
\text { tients (pre-diagnosis), this study had the lowest ratio of men:women of approximately } 2.5: 1 \text {, predomi- } \\
\text { nantly in the } 4 \text { th decade of life. Laboratory confirmation by titer or culture was required for inclusion in } \\
\text { analysis. } 10 \text { patients were identified by culture, } 45 \text { by four-fold rise in convalescent titer and } 1 \text { by a sin- } \\
\text { gle titer of at least 1:400. }\end{array}$ \\
\hline
\end{tabular}

Interventions

Oral doxycycline 200mg for 1 dose then $100 \mathrm{mg}$ every $12 \mathrm{~h}$ for 7 days, or azithromycin $1 \mathrm{~g}$ for 1 dose then $500 \mathrm{mg}$ once daily for 2 days.

\begin{tabular}{ll}
\hline Outcomes & The primary outcome for this trial was rate of cure defined by afebrile for 48 hours. \\
\hline Notes & $\begin{array}{l}\text { This trial was designed as a non-inferiority trial of azithromycin against doxycycline among febrile } \\
\text { patients. Data presented here was provided on correspondence with the senior author, Dr. Suputta- } \\
\text { mongkol, who verified for the authors results among those enrolled patients with laboratory confirmed } \\
\text { leptospirosis. }\end{array}$
\end{tabular}

Risk of bias

\begin{tabular}{|c|c|c|}
\hline Bias & Authors' judgement & Support for judgement \\
\hline $\begin{array}{l}\text { Random sequence genera- } \\
\text { tion (selection bias) }\end{array}$ & Low risk & $\begin{array}{l}\text { P. } 3260 \text {, "Independent, computer-generated, simple random allocation se- } \\
\text { quences were prepared for each study hospital by the investigator team in } \\
\text { Bangkok." }\end{array}$ \\
\hline $\begin{array}{l}\text { Allocation concealment } \\
\text { (selection bias) }\end{array}$ & Low risk & $\begin{array}{l}\text { P. } 3260 \text {, "These were sealed in an opaque envelope and numbered. The inves- } \\
\text { tigator in each study hospital assigned study participants to their treatment } \\
\text { groups after opening the sealed envelope." }\end{array}$ \\
\hline $\begin{array}{l}\text { Blinding (performance } \\
\text { bias and detection bias) } \\
\text { All outcomes }\end{array}$ & High risk & $\begin{array}{l}\text { P. } 3260 \text {, the two intervention options were dosed differently and were not used } \\
\text { in conjunction with placebo. }\end{array}$ \\
\hline $\begin{array}{l}\text { Incomplete outcome data } \\
\text { (attrition bias) } \\
\text { All outcomes }\end{array}$ & High risk & $\begin{array}{l}\text { P. } 3260 \text {, confirmation of leptospirosis depended upon analysis of both acute } \\
\text { and convalescent sera. } 89 \text { of } 296 \text { patients who were randomised were not as- } \\
\text { sessed at } 1 \text { to } 2 \text { weeks following discharge. For } 23 \text { of these patients nearer } \\
\text { term sera } 3 \text { to } 5 \text { days following admission was available and used for assessing } \\
\text { interval titer. }\end{array}$ \\
\hline $\begin{array}{l}\text { Selective reporting (re- } \\
\text { porting bias) }\end{array}$ & High risk & $\begin{array}{l}\text { Pre-defined outcome was time to defervescence and whether outcomes in the } \\
\text { Types of Outcomes section were completely discerned was not discernible. }\end{array}$ \\
\hline Other bias & Unclear risk & Not discerned. \\
\hline
\end{tabular}


Suputtamongkol 2004

\begin{tabular}{|c|c|c|}
\hline Methods & \multicolumn{2}{|c|}{ Prospective, multi-site, randomised, comparative trial. } \\
\hline Participants & \multicolumn{2}{|c|}{$\begin{array}{l}\text { Adults with less than } 15 \text { days of fever and laboratory confirmation of leptospirosis (all but two with } \\
\text { both serology and culture positivity). In contrast to the other trials, roughly } 3 \text { of } 4 \text { (rather than } 9 \text { of 10) } \\
\text { of the participants were men. Age ranges included mid-late adolescents and geriatric patients though } \\
\text { median was in the } 4 \text { th decade of life. }\end{array}$} \\
\hline Interventions & \multicolumn{2}{|c|}{$\begin{array}{l}\text { This trial assessed three treatment groups of parenteral induction therapy with penicillin } 1.5 \text { million } \\
\text { units every six hours, cefotaxime } 1 \text { gm six hours, or doxycycline loaded with } 200 \text { mg then } 100 \text { mg twice } \\
\text { daily; then, once afebrile and tolerating oral therapy, penicillin and cefotaxime patients were ran- } \\
\text { domised to either amoxicillin } 2 \text { g per day or doxycycline } 200 \text { mg per in divided doses, while those who } \\
\text { started with doxycycline transitioned to oral doxycycline therapy. Total course of therapy was } 7 \text { days. }\end{array}$} \\
\hline Outcomes & \multicolumn{2}{|c|}{ Death and duration of fever. } \\
\hline Notes & \multicolumn{2}{|c|}{$\begin{array}{l}\text { Two patients in the penicillin group and one in the cefotaxime group were excluded for uncertain out- } \\
\text { comes. They were included in these analyses as deaths. While the researchers prospectively char- } \\
\text { acterised disease severity at inclusion, outcome data were not stratified by disease severity. The re- } \\
\text { searchers assert that in multi-variate analysis disease severity (at least two organs with dysfunction) } \\
\text { and not antibiotic choice impact days of fever, though only level of statistical significance and not } \\
\text { strength of effect are provided. As standard deviation was not provided for the duration of fever, an over- } \\
\text { estimate based upon the range and presuming near normal distribution were used. }\end{array}$} \\
\hline \multicolumn{3}{|l|}{ Risk of bias } \\
\hline Bias & Authors' judgement & Support for judgement \\
\hline $\begin{array}{l}\text { Random sequence genera- } \\
\text { tion (selection bias) }\end{array}$ & Low risk & $\begin{array}{l}\text { P. } 1418, \text { "The independent, computer-generated random allocation sequences } \\
\text { were prepared" }\end{array}$ \\
\hline $\begin{array}{l}\text { Allocation concealment } \\
\text { (selection bias) }\end{array}$ & Low risk & P. 1418, "sealed in an opaque envelope, and the envelopes were numbered." \\
\hline $\begin{array}{l}\text { Blinding (performance } \\
\text { bias and detection bias) } \\
\text { All outcomes }\end{array}$ & High risk & $\begin{array}{l}\text { P. } 1418 \text {, each administered regimen differed and required investigator knowl- } \\
\text { edge of regimen in order to adjust for the possible presence of gram negative } \\
\text { sepsis. }\end{array}$ \\
\hline $\begin{array}{l}\text { Incomplete outcome data } \\
\text { (attrition bias) } \\
\text { All outcomes }\end{array}$ & Unclear risk & $\begin{array}{l}\text { P. } 1419 \text { Table } 1 \text {, while the number of excluded patients due to uncertain out- } \\
\text { come is provided, details and success of the following component of the pro- } \\
\text { tocol is not disclosed. }\end{array}$ \\
\hline $\begin{array}{l}\text { Selective reporting (re- } \\
\text { porting bias) }\end{array}$ & Unclear risk & Death was reported. Dialysis was not discernible. \\
\hline Other bias & Unclear risk & Not discerned. \\
\hline
\end{tabular}

Watt 1988

\begin{tabular}{ll}
\hline Methods & Prospective, single site, randomised, double-blind, placebo clinical trial. \\
\hline Participants & $\begin{array}{l}\text { Patients over } 16 \text { years of age presenting to a national infectious diseases hospital with suspected lep- } \\
\text { tospirosis and either a positive rapid IgM-based immunosorbent assay or a positive single serovar mi- } \\
\text { croagglutination assay, all later confirmed with multi-serovar based serologic assays or culture. Only } 7 \\
\text { participants had positive Leptospira cultures. The patients were predominantly men } 20 \text { to } 40 \text { years of } \\
\text { age. }\end{array}$
\end{tabular}


Watt 1988 (Continued)

Interventions $\quad 1,500,000$ units of parenteral sodium penicillin $\mathrm{G}$ administered four times daily for 7 days or a normal saline placebo.

\begin{tabular}{ll}
\hline Outcomes & Durations of fever and serum creatinine rise. \\
\hline Notes & $\begin{array}{l}\text { The trial was intended to focus on more severe disease but anuric patients or those so severely ill that } \\
\text { they could not provide consent were excluded, and no deaths or requirements for dialysis occurred. Se- } \\
\text { cond infections were disqualifying, but the screening algorithm for potential co-endemic diseases was } \\
\text { not provided. Patients were categorised as severely infected if serum creatinine was }>177 \mu \mathrm{mol} / \mathrm{L} \text { or } \\
\text { the patients were clinically jaundiced. }\end{array}$
\end{tabular}

\section{Risk of bias}

\begin{tabular}{lll}
\hline Bias & Authors' judgement & Support for judgement \\
\hline $\begin{array}{l}\text { Random sequence genera- } \\
\text { tion (selection bias) }\end{array}$ & Unclear risk & $\begin{array}{l}\text { P. 433, "randomly assigned to receive sodium penicillin G or placebo," method } \\
\text { of randomisation not disclosed. }\end{array}$ \\
\hline $\begin{array}{l}\text { Allocation concealment } \\
\text { (selection bias) }\end{array}$ & Unclear risk & Not discerned. \\
\hline $\begin{array}{l}\text { Blinding (performance } \\
\text { bias and detection bias) } \\
\text { All outcomes }\end{array}$ & Unclear risk & Not discerned. \\
\hline $\begin{array}{l}\text { Incomplete outcome data } \\
\text { (attrition bias) }\end{array}$ & Low risk & $\begin{array}{l}\text { P. 433, "patients were followed up a week and a month after discharge;" p434, } \\
\text { all leptospirosis patients completed therapy. }\end{array}$ \\
\hline $\begin{array}{l}\text { Selective reporting (re- } \\
\text { porting bias) }\end{array}$ & High risk & $\begin{array}{l}\text { Pre-defined outcome was time to defervescence and serum creatinine and } \\
\text { whether outcomes in the Types of outcomes section were completely dis- } \\
\text { cerned was not discernible. }\end{array}$ \\
\hline \begin{tabular}{l} 
Other bias \\
\hline
\end{tabular} & Unclear risk & \begin{tabular}{l} 
Not discerned. \\
\hline
\end{tabular}
\end{tabular}

ARDS = acute respiratory distress syndrome.

IgM = immunoglobulin $\mathrm{M}$.

$\mathrm{h}=$ hour.

$\mathrm{g}=$ gram.

$\mu \mathrm{mol} / \mathrm{L}=$ micromole.

$>=$ greater than.

Characteristics of excluded studies [ordered by study ID]

\begin{tabular}{ll}
\hline Study & Reason for exclusion \\
\hline Doherty 1955 & $\begin{array}{l}\text { This retrospective study assessed } 115 \text { cases of leptospirosis among Australian troops. The study at- } \\
\text { tempts an analysis of the impact of increasing dose of penicillin on shortening of the duration of } \\
\text { fever. It suggests mild decreases ( } 1 \text { to } 2 \text { days) of duration of fever and well describes the fever curve } \\
\text { of untreated and treated leptospirosis. It did not contribute information on adverse events. }\end{array}$ \\
\hline Fairburn 1956 & $\begin{array}{l}\text { This study prospectively assessed British troops deployed to an endemic area (Malaya). Ill troops } \\
\text { with suspected leptospirosis all of who were mildly ill were divided among three groups: control, } \\
\text { penicillin therapy or chloramphenicol therapy. A case definition for leptospirosis was not provid- } \\
\text { ed. Confirmation by a serologic method or culture was reported in } 50 \text { of the } 83 \text { patients. However, } \\
\text { the results could not be explored based upon this confirmation and serologic categorizations and }\end{array}$
\end{tabular}




\begin{tabular}{|c|c|}
\hline Study & Reason for exclusion \\
\hline & $\begin{array}{l}\text { methods have evolved considerably since study execution. No information on randomisation was } \\
\text { provided. Adverse events of therapy were not discussed. }\end{array}$ \\
\hline Hall 1951 & $\begin{array}{l}\text { This study reports treatment performance in } 67 \text { cases of leptospirosis in Puerto Rico. Chloram- } \\
\text { phenicol, aureomycin, penicillin, terramycin, streptomycin, aureomycin and streptomycin, cor- } \\
\text { tisone and aureomycin were employed. The article implies that these treatment groups were un- } \\
\text { dertaken prospectively and sequentially in block, however it acknowledges variability in how the } \\
\text { treatments were applied. Also it was unclear whether twelve contemporary controls were used in } \\
\text { their analyses. With regards to adverse events, the study asserted that there was no difference in } \\
\text { the frequency or severity of renal injury between treated and untreated patients. }\end{array}$ \\
\hline Munnich 1972 & $\begin{array}{l}\text { This is a single arm observational study of an oral ampicillin formulation of ampicillin in the } \\
\text { treatment of leptospirosis. The study did not report any adverse events. The observation- } \\
\text { al series appears to have continued with a related amoxycillin formulation in Chemotherapy } \\
\text { 1976;22(6):372-80. }\end{array}$ \\
\hline Russell 1958 & $\begin{array}{l}\text { This study prospectively assessed British troops deployed to an endemic area (Malaya). Ill troops } \\
\text { with suspected leptospirosis divided among two groups: ascorbic acid placebo or parenteral oxyte- } \\
\text { tracycline. Definition for leptospirosis in a patient was not provided. Confirmation by a serolog- } \\
\text { ic method or culture was reported to have occurred in all } 52 \text { patients. However, the results could } \\
\text { not be explored based upon this confirmation, and serologic categorisations and methods have } \\
\text { evolved considerably since study execution. The patients were alternately placed in each group } \\
\text { without randomisation. This test drug is no longer employed in common practice. }\end{array}$ \\
\hline
\end{tabular}

\section{DATA AND ANALYSES}

\section{Comparison 1. Antibiotics versus placebo}

\begin{tabular}{lllll}
\hline Outcome or subgroup title & $\begin{array}{l}\text { No. of } \\
\text { studies }\end{array}$ & $\begin{array}{l}\text { No. of } \\
\text { partici- } \\
\text { pants }\end{array}$ & Statistical method & Effect size \\
\hline 1 Death & 4 & 403 & Odds Ratio (M-H, Random, 95\% Cl) & $1.16[0.23,5.95]$ \\
\hline 2 Days of hospitalisation & 1 & & Mean Difference (IV, Fixed, 95\% Cl) & Totals not selected \\
\hline 3 Days of clinical illness & 2 & 71 & Mean Difference (IV, Random, 95\% Cl) & $-4.04[-8.66,0.58]$ \\
\hline 4 Dialysis employed & 2 & 332 & Odds Ratio (M-H, Fixed, 95\% Cl) & $1.54[0.91,2.60]$ \\
\hline 5 Days of fever & 1 & & Mean Difference (IV, Fixed, 95\% Cl) & Totals not selected \\
\hline
\end{tabular}

Analysis 1.1. Comparison 1 Antibiotics versus placebo, Outcome 1 Death.

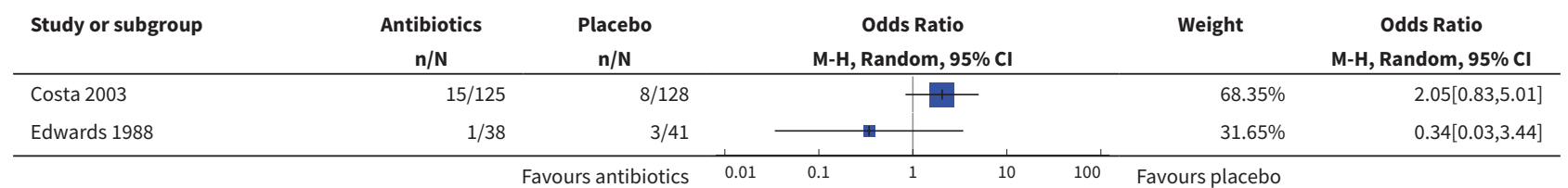




\begin{tabular}{|c|c|c|c|c|c|}
\hline Study or subgroup & $\begin{array}{c}\text { Antibiotics } \\
n / N\end{array}$ & $\begin{array}{c}\text { Placebo } \\
n / N\end{array}$ & $\begin{array}{c}\text { Odds Ratio } \\
\text { M-H, Random, } 95 \% \mathrm{Cl}\end{array}$ & Weight & $\begin{array}{c}\text { Odds Ratio } \\
\text { M-H, Random, } 95 \% \mathrm{Cl}\end{array}$ \\
\hline McClain 1984 & $0 / 14$ & $0 / 15$ & & & Not estimable \\
\hline Watt 1988 & $0 / 23$ & $0 / 19$ & & & Not estimable \\
\hline Total $(95 \% \mathrm{CI})$ & 200 & 203 & & $100 \%$ & $1.16[0.23,5.95]$ \\
\hline \multicolumn{6}{|c|}{ Heterogeneity: $\operatorname{Tau}^{2}=0.81 ; \mathrm{Chi}^{2}=2.01, \mathrm{df}=1(\mathrm{P}=0.16) ; \mathrm{I}^{2}=50.28 \%$} \\
\hline Test for overall effect & & & & & \\
\hline
\end{tabular}

Analysis 1.2. Comparison 1 Antibiotics versus placebo, Outcome 2 Days of hospitalisation.

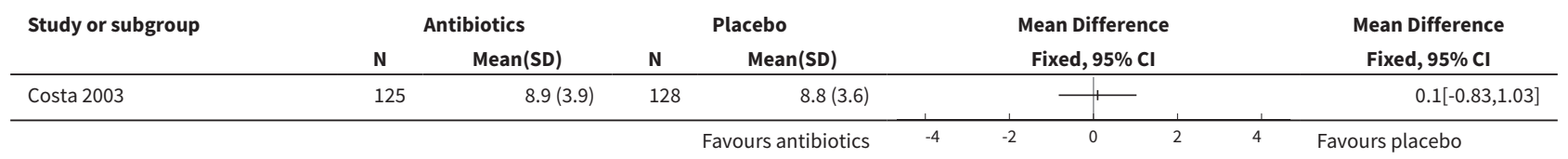

Analysis 1.3. Comparison 1 Antibiotics versus placebo, Outcome 3 Days of clinical illness.

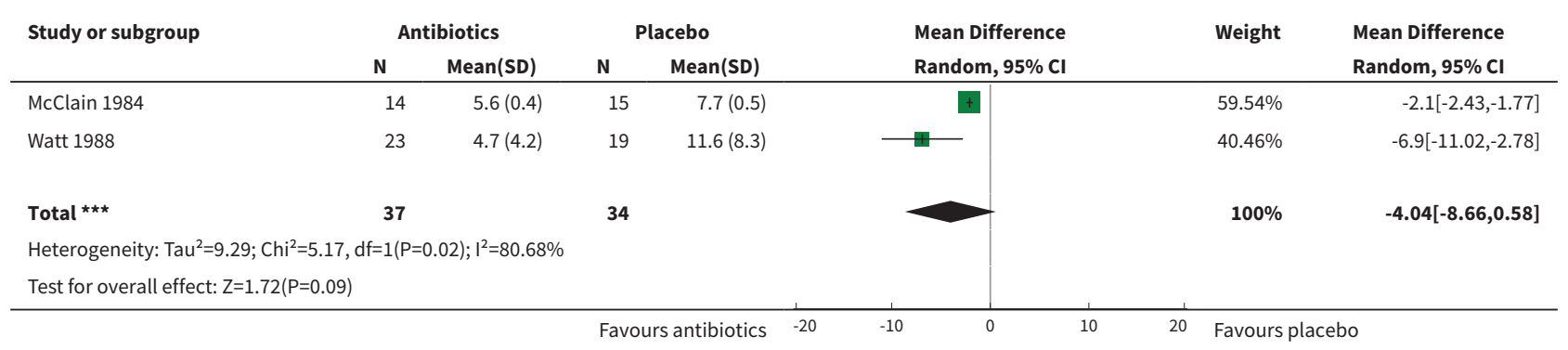

Analysis 1.4. Comparison 1 Antibiotics versus placebo, Outcome 4 Dialysis employed.

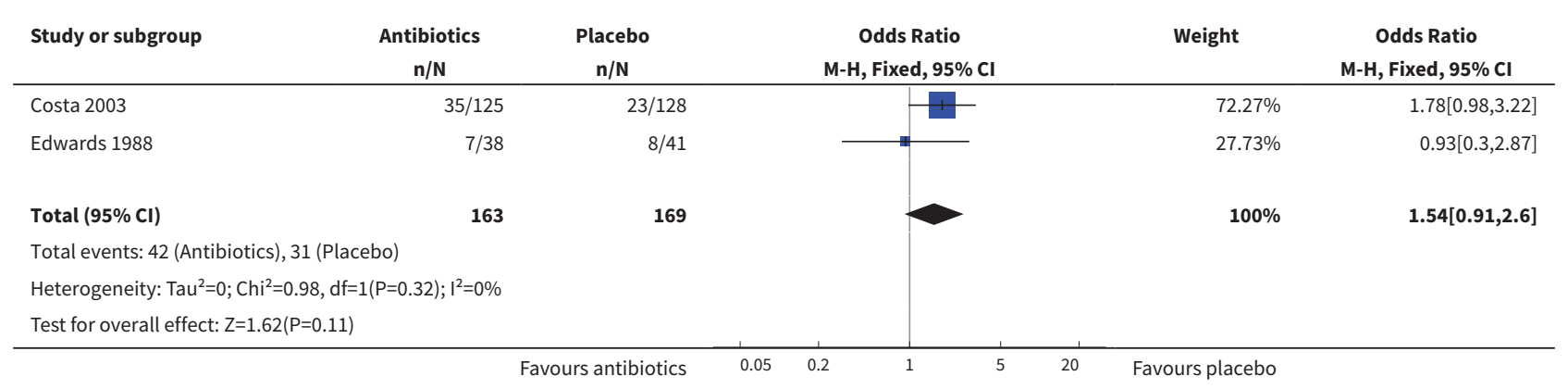


Analysis 1.5. Comparison 1 Antibiotics versus placebo, Outcome 5 Days of fever.

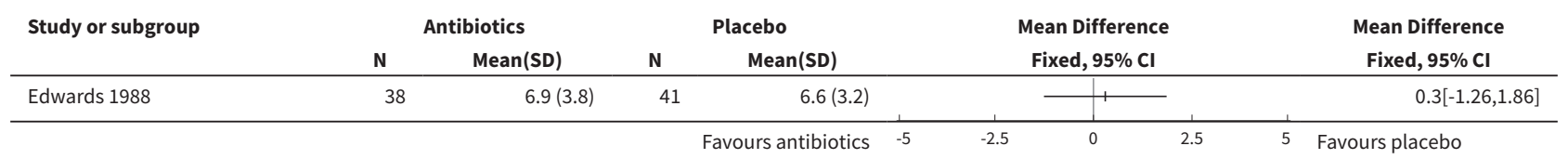

\section{Comparison 2. Cephalosporin versus penicillin}

\begin{tabular}{lllll}
\hline $\begin{array}{l}\text { Outcome or subgroup ti- } \\
\text { tle }\end{array}$ & $\begin{array}{l}\text { No. of } \\
\text { studies }\end{array}$ & $\begin{array}{l}\text { No. of par- } \\
\text { ticipants }\end{array}$ & Statistical method & Effect size \\
\hline 1 Death & 2 & 351 & Odds Ratio (M-H, Fixed, 95\% Cl) & $0.65[0.23,1.87]$ \\
\hline 2 Days of fever & 2 & 348 & Mean Difference (IV, Fixed, 95\% Cl) & $-0.03[-0.09,0.03]$ \\
\hline
\end{tabular}

Analysis 2.1. Comparison 2 Cephalosporin versus penicillin, Outcome 1 Death.

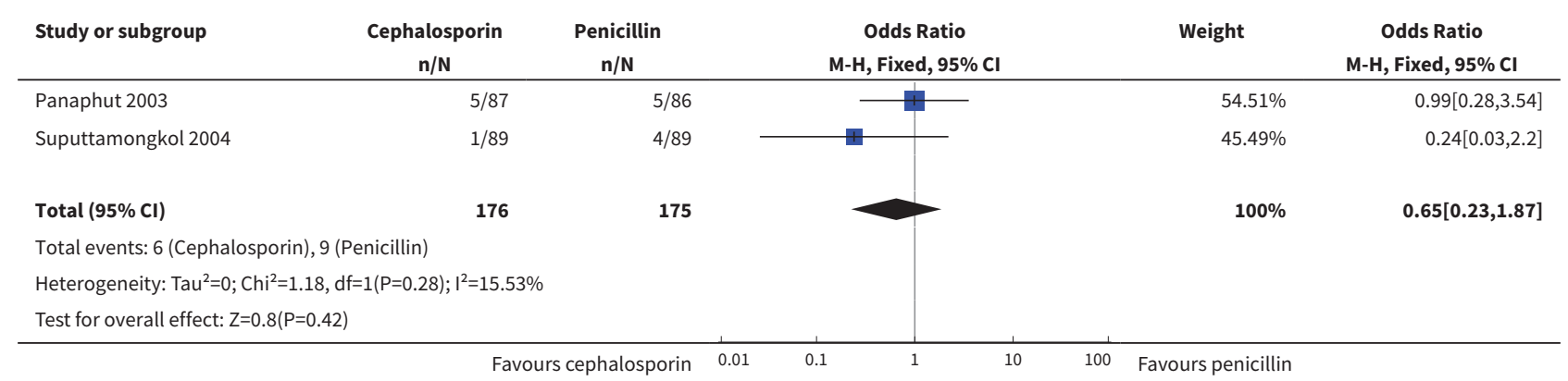

Analysis 2.2. Comparison 2 Cephalosporin versus penicillin, Outcome 2 Days of fever.

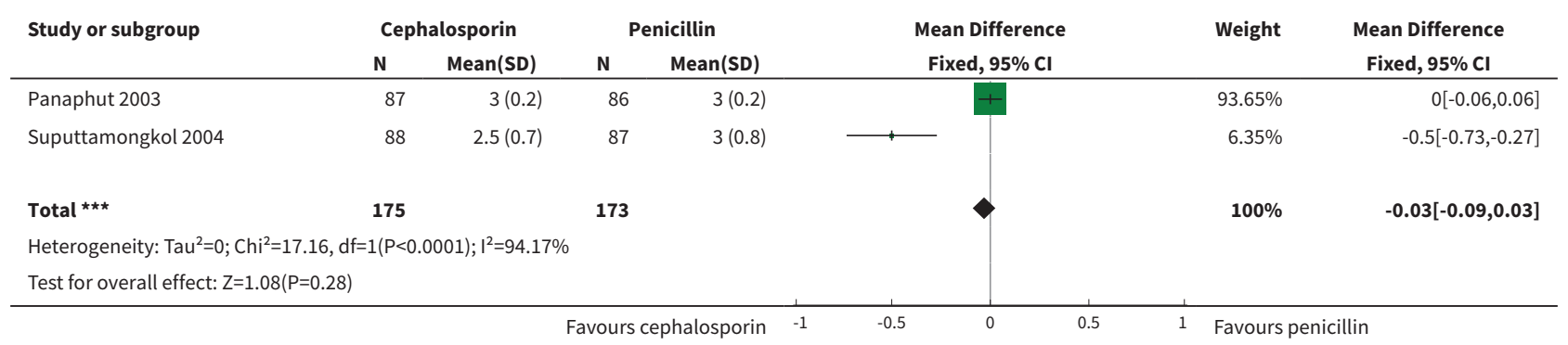


Comparison 3. Doxycycline versus penicillin

\begin{tabular}{llll}
\hline $\begin{array}{l}\text { Outcome or subgroup } \\
\text { title }\end{array}$ & $\begin{array}{l}\text { No. of } \\
\text { studies }\end{array}$ & $\begin{array}{l}\text { No. of } \\
\text { partici- } \\
\text { pants }\end{array}$ & Statistical method \\
\hline 1 Death & 1 & Odds Ratio (M-H, Fixed, 95\% Cl) & Mean Difference (IV, Fixed, 95\% Cl) \\
\hline 2 Days of fever & 1 & Totals not selected & Totals not selected \\
\hline
\end{tabular}

Analysis 3.1. Comparison 3 Doxycycline versus penicillin, Outcome 1 Death.

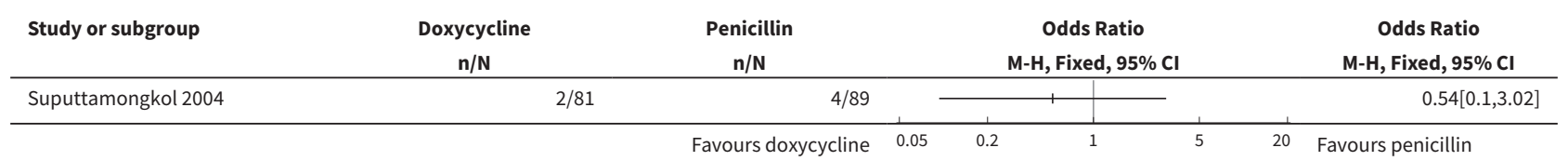

Analysis 3.2. Comparison 3 Doxycycline versus penicillin, Outcome 2 Days of fever.

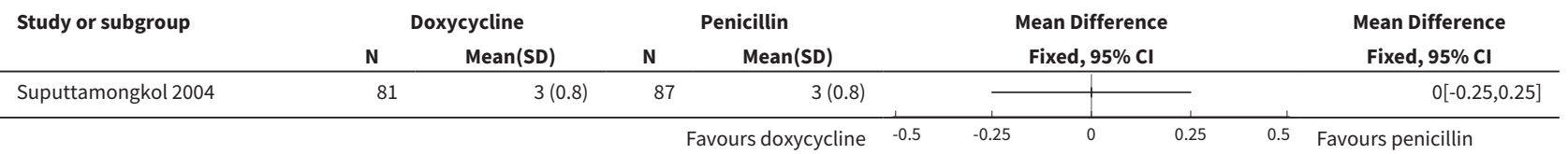

Comparison 4. Azithromycin versus doxycycline

\begin{tabular}{lllll}
\hline Outcome or subgroup title & $\begin{array}{l}\text { No. of } \\
\text { studies }\end{array}$ & $\begin{array}{l}\text { No. of } \\
\text { partici- } \\
\text { pants }\end{array}$ & Statistical method & Effect size \\
\hline 1 Afebrile within 48 hours of initiation of therapy & 1 & & Odds Ratio (M-H, Fixed, 95\% Cl) & $\begin{array}{l}\text { Totals not select- } \\
\text { ed }\end{array}$ \\
\hline
\end{tabular}

Analysis 4.1. Comparison 4 Azithromycin versus doxycycline, Outcome 1 Afebrile within $\mathbf{4 8}$ hours of initiation of therapy.

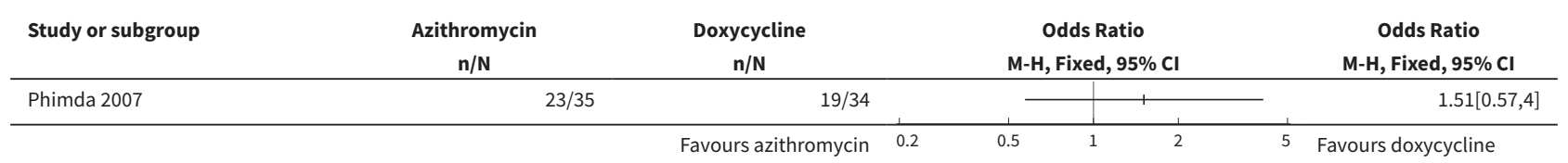


Comparison 5. Cephalosporin versus doxycycline

\begin{tabular}{lllll}
\hline $\begin{array}{l}\text { Outcome or subgroup ti- } \\
\text { tle }\end{array}$ & $\begin{array}{l}\text { No. of } \\
\text { studies }\end{array}$ & $\begin{array}{l}\text { No. of partici- } \\
\text { pants }\end{array}$ & Statistical method & Effect size \\
\hline 1 Death & 1 & & Odds Ratio (M-H, Fixed, 95\% Cl) & Totals not selected \\
\hline
\end{tabular}

Analysis 5.1. Comparison 5 Cephalosporin versus doxycycline, Outcome 1 Death.

\begin{tabular}{|c|c|c|c|c|c|c|c|}
\hline \multirow{2}{*}{$\begin{array}{l}\text { Study or subgroup } \\
\text { Suputtamongkol } 2004\end{array}$} & $\begin{array}{c}\text { Cephalosporin } \\
\mathrm{n} / \mathrm{N}\end{array}$ & $\begin{array}{c}\text { Doxycycline } \\
n / N\end{array}$ & \multicolumn{3}{|c|}{$\begin{array}{c}\text { Odds Ratio } \\
\text { M-H, Fixed, } 95 \% \mathrm{Cl}\end{array}$} & & \multirow{2}{*}{$\begin{array}{c}\begin{array}{c}\text { Odds Ratio } \\
\text { M-H, Fixed, } \mathbf{9 5} \% \mathbf{~ C l}\end{array} \\
0.45[0.04,5.1\end{array}$} \\
\hline & $1 / 88$ & $2 / 81$ & & 1 & 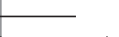 & & \\
\hline
\end{tabular}

APPENDICES

Appendix 1. Search Strategies

\begin{tabular}{|c|c|c|}
\hline Database & Span of Search & Search strategy \\
\hline $\begin{array}{l}\text { The Cochrane Hepa- } \\
\text { to-Biliary Group Con- } \\
\text { trolled Trials Register }\end{array}$ & October 2011. & leptospir AND (treat* OR therap*) \\
\hline $\begin{array}{l}\text { Cochrane Cen- } \\
\text { tral Register of } \\
\text { Controlled Trials } \\
\text { (CENTRAL) in The } \\
\text { Cochrane Library }\end{array}$ & Issue 3, 2011 & $\begin{array}{l}\# 1 \text { MeSH descriptor Anti-Bacterial Agents explode all trees } \\
\# 2 \text { treat* OR therap* }^{\star} \\
\# 3 \text { (\#1 OR \#2) } \\
\# 4 \text { MeSH descriptor Leptospirosis explode all trees } \\
\# 5 \text { leptospir* } \\
\# 6 \text { (\#4 OR \#5) \#7 (\#3 AND \#6) }\end{array}$ \\
\hline MEDLINE (Ovid SP) & $\begin{array}{l}\text { From } 1948 \text { to Octo- } \\
\text { ber } 2011 .\end{array}$ & $\begin{array}{l}\text { 1. exp Anti-Bacterial Agents/ } \\
\left.\text { 2. (treat* or therap }{ }^{\star}\right) \text {.mp. [mp=title, original title, abstract, name of substance word, } \\
\text { subject heading word, unique identifier] } \\
\text { 3. } 1 \text { or } 2 \\
\text { 4. exp Leptospirosis/ } \\
\text { 5. leptospir*.mp. [mp=title, original title, abstract, name of substance word, subject } \\
\text { heading word, unique identifier] } \\
\text { 6. } 4 \text { or } 5 \\
\text { 7. } 3 \text { and } 6 \\
\text { 8. (random* or blind }{ }^{\star} \text { or placebo* or meta-analysis).mp. [mp=title, original title, ab- } \\
\text { stract, name of substance word, subject heading word, unique identifier] }\end{array}$ \\
\hline
\end{tabular}




EMBASE (Ovid SP) From 1980 to Octo-
ber 2011.
1. exp antibiotic therapy/

2. $\left(\right.$ treat $^{\star}$ or therap $\left.{ }^{\star}\right) \cdot \mathrm{mp}$. [mp=title, abstract, subject headings, heading word, drug trade name, original title, device manufacturer, drug manufacturer name]

3. 1 or 2

4. exp leptospirosis/

5. leptospir*.mp. [mp=title, abstract, subject headings, heading word, drug trade name, original title, device manufacturer, drug manufacturer name]

6.4 or 5

7. 3 and 6

8. (random* or blind* or placebo* or meta-analysis).mp. [mp=title, abstract, subject headings, heading word, drug trade name, original title, device manufacturer, drug manufacturer name]

9. 7 and 8

\section{CONTRIBUTIONSOF AUTHORS}

Conceiving the review: [pre-existing]

Designing the review: DMB.

Co-ordinating the review: DMB.

Data collection for the review: DMB.

Developing search strategy: DMB, RC, CHBG Staff.

Undertaking searches: DMB, CHBG Staff.

Screening search results: DMB, RC.

Organising retrieval of papers: DMB.

Screening retrieved papers against inclusion criteria: DMB, RC.

Appraising quality of papers: DMB, RC.

Abstracting data from papers: DMB, RC.

Writing to authors of papers for additional information: DMB.

Providing additional data about papers: DMB by responding authors.

Obtaining and screening data on unpublished studies: for abstracts, DMB.

Data management for the review: DMB.

Entering data into RevMan: DMB.

Analysis of data: DMB, RC.

Interpretation of data: DMB, RC.

Providing a methodological perspective: DMB, RC.

Providing a clinical perspective: DMB, RC.

Providing a policy perspective: DMB, RC.

Providing a consumer perspective: DMB, RC.

Writing the review: DMB, RC.

Providing general advice on the review: CHBG Staff. 
Securing funding for the review: NA.

Performing previous work that was the foundation of current study: NA.

\section{DECLARATIONS OF INTEREST}

None known.

\section{DIFFERENCES BETWEEN PROTOCOLAND REVIEW}

Multiple analyses for missing data were not indicated. Handling of three patient outcomes in a specific case is discussed (Risk of bias in included studies).

\section{NOTES}

This review replaces the review by Guidugli et al (Guidugli 2000).

Additional affiliations.

DMB - Program Director, U.S. Military Tropical Medicine, Navy Medicine Manpower Personnel Training and Education (NAVMED MPT\&E), Bethesda MD; and, Assistant Professor, Divisions of Tropical Public Health and Infectious Diseases, Departments of Preventive Medicine and Biometrics, and Medicine, Uniformed Services University, Bethesda MD.

RC - Director, Division of Tropical Public Health, Department of Preventive Medicine and Biometrics, Uniformed Services University, Bethesda MD.

These views are those of the authors and do not necessarily reflect those of Navy Medicine Manpower, Personnel, Training \& Education Command, Departments of the Army or Navy, Uniformed Services University, Department of Defense, or the U.S. Government.

\section{IN DEX TERMS}

\section{Medical Subject Headings (MeSH)}

Anti-Bacterial Agents [*therapeutic use]; Cephalosporins [therapeutic use]; Doxycycline [therapeutic use]; Leptospirosis [ ${ }^{\star} d r u g$ therapy] [mortality]; Penicillins [therapeutic use]; Randomized Controlled Trials as Topic

\section{MeSH check words}

Humans 